\title{
O „topografii pustki” w krajobrazie kulturowym Miejsca niepamięci i nie-miejsca pamięci w kontekście mordów dokonanych na Żydach w Polsce w pierwszych miesiącach po drugiej wojnie światowej
}

\begin{abstract}
Wieńcząca drugą wojnę światową klęska hitlerowskich Niemiec nie oznaczała kresu dramatu Żydów na ziemiach polskich. Jeszcze przed zakończeniem największego w dziejach świata konfliktu na terenach opuszczonych przez okupacyjne wojska niemieckie wielu ocalałych z Holokaustu, często bezdomnych, osamotnionych i wylęknionych, nadal doznawało przemocy. Upamiętnienia w przestrzeni doczekały się tylko niektóre spośród wielu ofiar (i aktów) powojennego terroru antyżydowskiego. Podobnie zresztą w nikłym stopniu formą publicznej komemoracji objęte zostały wcześniejsze, wojenne przypadki kolektywnych mordów dokonanych na Żydach przez polskich chrześcijan. Gdy jednak już doszło do topograficznego oznaczenia informacji o aktach rozgrywającego się w cieniu Holokaustu dramatu, nie przywracano na ogół pełnej prawdy o sprawcach (ich proweniencji etnicznej czy osadzeniu terytorialnym) oraz przebiegu tych wydarzeń.
\end{abstract}

Słowa kluczowe: Żydzi, Holokaust, przemoc antyżydowska, okres powojenny, miejsca pamięci, miejsca niepamięci, nie-miejsca pamięci.

\section{Wprowadzenie O pamięci miejsc w dyskursie mniejszości z większością}

Na krajobraz kulturowy, będący wynikiem przekształcania - szeroko rzecz ujmując - krajobrazu naturalnego pod wpływem rozwoju cywilizacyjnego, składa się ogół obserwowalnych obiektów, stanowiących formę zespolenia oddziaływań przyrodniczych i antropogenicznych ${ }^{1}$. W tej wielości tworzących ten krajobraz komponentów znajdują się i takie, które odzwierciedlają występowanie grup ludności połączonych mniej lub bardziej wykształconym poczuciem odrębności, wyrażanym w kategoriach narodowych lub etnicznych (zbieżnych nierzadko

${ }^{1}$ Więcej na temat teoretycznych ujęć i badań krajobrazu kulturowego m.in. w: S. Schama (1996), Z. Jabłoński (1998), E. Orłowska (2005), U. Myga-Piątek (2012), J. Plit (2016). 
z religijnymi). Rozwój świadomości etnicznej (narodowej) oraz możliwość transmisji samoidentyfikacji narodowościowej (religijnej) w kierunku różnorodnych działań w zakresie życia zbiorowego następują w sposób najbardziej pożądany $\mathrm{w}$ warunkach posiadania przez wspomniane grupy zinstytucjonalizowanych form, zwłaszcza tych o charakterze państwowym, stanowiących dla nich prawne, administracyjne i gospodarcze ramy, które uzupełniają i wzmacniają występowanie owych społeczności. Komfort nieskrępowanej egzystencji na obszarze wyznaczonym granicami politycznymi zazwyczaj ma zasiedlająca go większość narodowa (religijna). Osoby skupione w mniejszych liczebnie wspólnotach często nie są w stanie wyegzekwować przywilejów i praw przypisanych grupie liczebnie dominującej, mimo że współcześnie w demokratycznych państwach prawa przywiązuje się dużą wagę do ochrony tych społeczności. Nierównoprawne relacje większości z mniejszościami narodowymi odciskają swoje piętno - poza wieloma dziedzinami życia - również w przestrzeni: w sposobach i formach jej zajmowania, organizowania, oznaczania, nazywania.

W Polsce jedną $\mathrm{z}$ wielu mniejszości pozostających przez stulecia w złożonych, choć nierównoprawnych relacjach z narodem katolickim (a zarazem szlacheckim), którego szeroko rozumianych interesów strzegli rządzący, niemal w całości się z nimi identyfikując, byli Żydzi. Spychani - z różnym natężeniem i często wybiórczo - na margines życia społecznego, zobligowani na ogół (aż do połowy XIX w.) do zajmowania wskazanych im miejsc w przestrzeni i organizowania ich w sposób nie zawsze zgodny z własnymi potrzebami, spotkali się jednak ze strony rządzących ze względnym poszanowaniem dla swojej kulturowej odmienności, wyrażającej się w miarę nieskrępowaną materialną egzystencją i pewną swobodą uprawiania kultu religijnego. Wymiernym efektem tych warunków było ukształtowanie się na ziemiach polskich po upływie kilku stuleci największego w świecie skupienia narodu żydowskiego, będącego jednocześnie najważniejszym ośrodkiem intelektualnym i kulturowym tej społeczności. Ten wyjątkowy dorobek legł jednak w gruzach w połowie XX w., w wyniku przeprowadzonej przez Trzecią Rzeszę eksterminacji około 3 mln Żydów (90\% ogółu ludności żydowskiej) oraz zniszczenia unikatowej, tworzonej przez nich od tysiąca lat kultury duchowej i materialnej (Adelson 1993, s. 387, Cała, Datner-Śpiewak 1997, s. 9, Datner, Melchior 1997, s. 70-71, Rykała 2011, s. 237, Żbikowski 2017, s. 9).

Po wielu ludzkich istnieniach, unicestwionych w miejscach masowej kaźni, nie pozostał żaden ślad. Bez chociażby takiego wymiaru zakotwiczenia w rzeczywistości najbliżsi zostali pozbawieni sposobności opłakania losu ofiar; notabene z tych, którzy mogliby ten gest uczynić, ocalało niewielu. W poetyckim uniesieniu dojmującemu przygnębieniu niemożnością pochylenia się nad losem ofiar w miejscach przerwania ich życia dał wyraz Julian Tuwim, pisząc: 
My, którzy nawet grobów dzieci naszych i matek nie odnajdziemy - tak się warstwami poukładają, tak się na całą ojczyznę wszerz rozpostrą, w jedno pogrzebanie! I nie będzie upatrzonego miejsca, żebyś mógł na nim kwiaty położyć, ale, jak siewca ziarno, będziesz je szerokim rozmachem rąk rozrzucał. Może przypadkiem trafisz (Tuwim 1993, s. 18).

Nadciągający koniec drugiej wojny światowej i nieuchronna klęska hitlerowskich Niemiec nie oznaczały jednak kresu dramatu Żydów na ziemiach polskich. $\mathrm{Na}$ terenach opuszczonych przez okupacyjne wojska niemieckie wielu ocalałych, często bezdomnych, osamotnionych i wylęknionych, zmagających się z traumą i bólem po stracie najbliższych, nadal doznawało przemocy. Winni przestępstw na ogół nie zostawali zidentyfikowani, a jeśli nawet ustalono ich tożsamość, to akty, których się dopuścili, nie przeszkodziły im dostąpić we współczesnej Polsce zaszczytu znalezienia się w panteonie bohaterów historii pisanej przez większość (by wspomnieć chociażby Józefa Kurasia, ps. Ogień ${ }^{2}$, odpowiedzialnego m.in. za mordy Żydów na Podhalu, czy - terroryzującego prawosławną ludność Podlasia i uznanego w związku z tym za winnego zbrodni ludobójstwa - Romualda Rajsa, ps. Bury $^{3}$ ). Z kolei miejsca tych traumatycznych wydarzeń, naznaczone cierpieniem i śmiercią ocalałych z Zagłady, nie stały się dla lokalnej czy ponadlokalnej społeczności punktami zaczepienia dla rozpamiętywania. Ułożyły się, „rozpostarły” w kolejną warstwę „pogrzebania”, bez „upatrzonego miejsca” do złożenia kwiatów, pogrążenia się w zadumie, zatrzymania się.

Główne cele artykułu to wyjaśnienie przyczyn oraz analiza politycznych i społeczno-przestrzennych uwarunkowań antyżydowskiej przemocy w Polsce po dru-

${ }^{2}$ Oddziałowi dowodzonemu przez Kurasia przypisuje się mord 12 Żydów (w dokumentach archiwalnych figuruje też liczba 11), dokonany w okolicach Krościenka 2 maja 1946 r. (Archiwum Akt Nowych (dalej: AAN), Ministerstwo Administracji Publicznej (dalej: MAP), Departament Polityczny (dalej: DP), Wydział Narodowościowy (dalej: WN), sygn. 787, Odpis pisma dr. Horowitza, przewodniczącego, i dr. Reichmana, sekretarza generalnego Wojewódzkiego Komitetu Żydowskiego (dalej: WKŻ) w Krakowie, skierowanego do Centralnego Komitetu Żydów w Polsce (dalej: CKŻP), 4 maja 1946 r., w sprawie mordu Żydów pod Krościenkiem; Archiwum Żydowskiego Instytutu Historycznego (dalej: AŻIH), CKŻP, Centralna Komisja Specjalna (CKS), sygn. 303/XVIII/20, Wykaz mordów dokonywanych na ludności żydowskiej; Gross 2008, s. 58). Spośród antykomunistycznych partyzantów właśnie temu watażce zbrojnego podziemia przypisuje się najwięcej (blisko 50) śmiertelnych ofiar wśród ocalałych Żydów (Grabski, Rykała 2010, s. 403). Więcej na temat tych mordów m.in. w: J. Wójcik (2016).

${ }^{3}$ Więcej na ten temat: A. Moroz (2015, s. 61-91). O pacyfikacji wsi białoruskich przez Rajsa zob. też: wywiad Aliny Pospischil z Adamem Puławskim, historykiem specjalizującym się w badaniu stosunku polskiego państwa podziemnego do sytuacji Żydów w okresie drugiej wojny światowej (IPN wyrzuca naukowców... 2018, s. 22). 
giej wojnie światowej, a także przywrócenie pamięci ${ }^{4}$ o (niektórych) ofiarach i miejscach zbiorowych mordów dokonywanych na Żydach.

Rozpiętość czasową analizy wyznaczają: z jednej strony, wyzwolenie poszczególnych ziem spod okupacji niemieckiej, z drugiej - akcja repatriacyjna ludności żydowskiej ze Związku Radzieckiego, przypadająca na pierwsze półrocze 1946 r.

\section{Nie tylko w cieniu Zaglady Miejsca przemilczania niewygodnych dla większości faktów}

Wspominając o unicestwieniu wyjątkowego w historii Żydów skupienia na ziemiach polskich, do którego doprowadziło bezprzykładne bestialstwo niemieckich oprawców, należy dodać, że w cieniu Holokaustu, a nierzadko i we współpracy z jego głównymi sprawcami, agresji i terroru dopuszczali się również liczni przedstawiciele polskiego społeczeństwa ${ }^{5}$. Najwięcej przerażających skalą aktów kolektywnej przemocy wobec ludności żydowskiej miało miejsce głównie na tych terenach zdobytych przez Niemców, które do połowy $1941 \mathrm{r}$. były okupowane przez Związek Radziecki. Należały do nich: Podlasie (zwłaszcza jego część pomiędzy Grajewem a Łomżą) ${ }^{6}$ oraz wschodnia Galicja - obszary słabo zurbanizowane i od-

${ }^{4}$ Historyk P. Nora (1984 s. 25), interpretując w kategoriach historycznych i kulturowych pamięć, czyli zdolność do rejestrowania i przywoływania informacji, wrażeń zmysłowych i skojarzeń, podkreślał, że jest ona ,życiem” podtrzymywanym nieustannie przez „żyjących”, a w związku z tym podlega ciągłej ewolucji, „otwartej na dialektykę spełnienia i amnezji, nie troszcząc się o kolejne deformacje, podatność na zabiegi instrumentalizacyjne czy manipulacyjne" (za: Delaperriére 2013, s. 50).

${ }^{5}$ Liczne przypadki współudziału Polaków w zbrodniach na Żydach, opisane na podstawie bogatych materiałów źródłowych, zwłaszcza dekretu Polskiego Komitetu Wyzwolenia Narodowego z dnia 31 sierpnia 1944 r., o wymiarze kary dla faszystowsko-hitlerowskich zbrodniarzy winnych zabójstw i znęcania się nad ludnością cywilną i jeńcami oraz dla zdrajców Narodu Polskiego (tzw. sierpniówki), udokumentowali m.in. B. Engelking (2011) w pracy Jest taki piękny słoneczny dzień. Losy Żydów szukających ratunku na wsi polskiej 1942-1945, J. Grabowski (2011) - w Judenjagd. Polowanie na Żydów 19421945. Studium dziejów pewnego powiatu, oraz oboje autorzy, wydając pod wspólną redakcją Zarys krajobrazu. Wieś polska wobec zagłady Żydów 1942-1945 (2011). Współsprawstwo części narodu polskiego w eksterminacji żydowskich współobywateli, ujawnione przy zastosowaniu klucza przestrzennego (w podziale na powiaty), to także temat ostatniego dzieła pod redakcją obojga badaczy, zatytułowanego Dalej jest noc. Losy Żydów w wybranych powiatach okupowanej Polski, t. 1 i 2 (2018).

${ }^{6}$ W latach 1939-1941 tereny te wchodziły w skład obwodu białostockiego, tzw. Zachodniej Białorusi, włączonej do Białoruskiej Socjalistycznej Republiki Radzieckiej, a po zajęciu ich przez Niemców znalazły się w granicach okręgu białostockiego, będącego częścią Prus Wschodnich. 
stające pod względem cywilizacyjnym od reszty przedwojennej Polski, z dużym udziałem Żydów w miejscowej populacji (w niektórych miasteczkach przekraczającym nierzadko 50\%), a także ich wkładem w rozwój miejscowego handlu i rzemiosła (ryc. 1). Fala przemocy - układająca się w sekwencję kilkudziesięciu aktów zbiorowych wystąpień przeciw ludności żydowskiej - ogarnęła te ziemie w czerwcu i lipcu 1941 r., a więc w okresie, kiedy znajdowały się one pod jurysdykcją hitlerowskich Niemiec (ryc. 2).

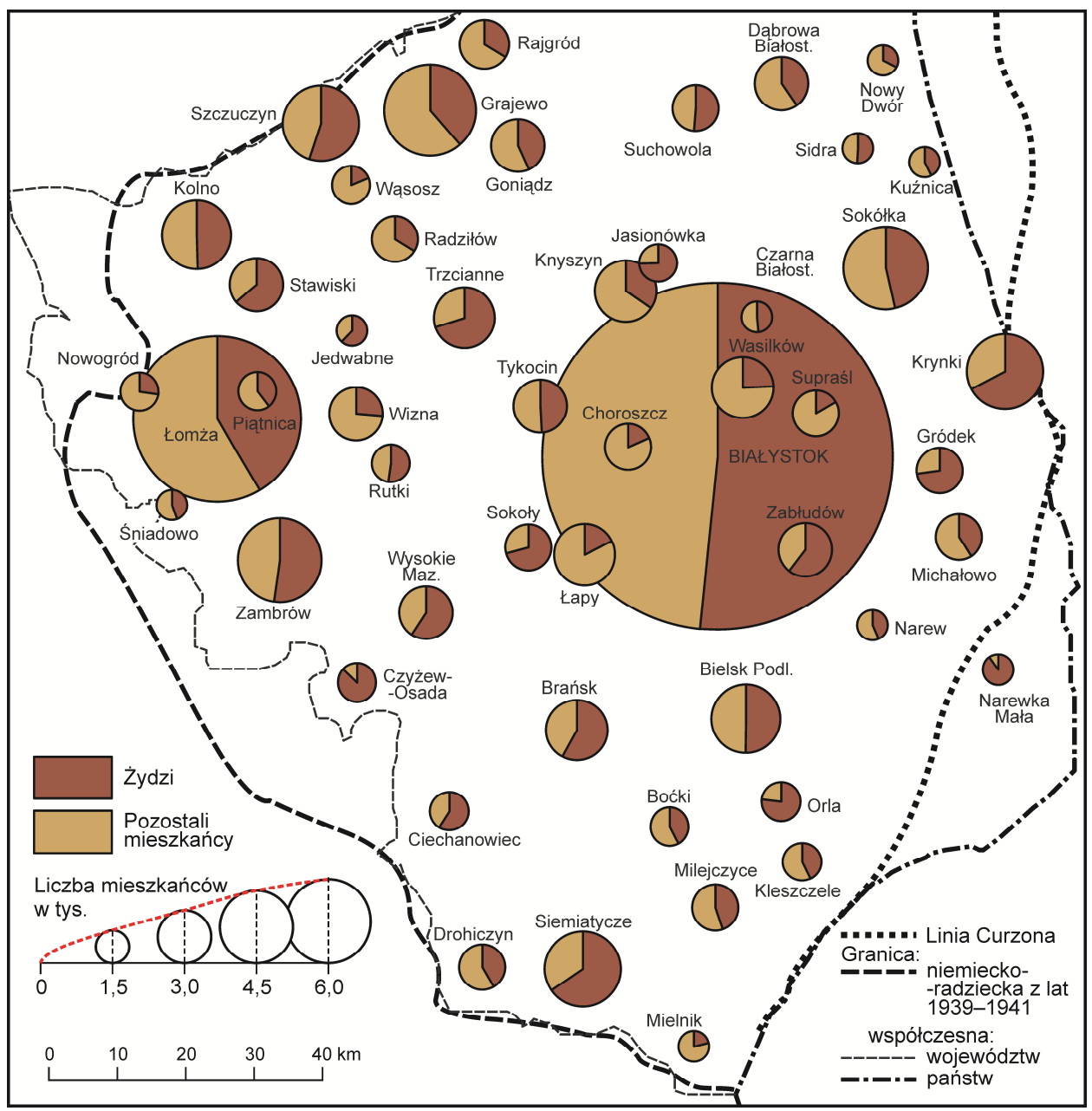

Ryc. 1. Udział ludności żydowskiej w populacji wybranych miast Podlasia i wschodniego Mazowsza w końcu lat 30. i na początku lat 40. XX w. Źródło: opracowanie własne 


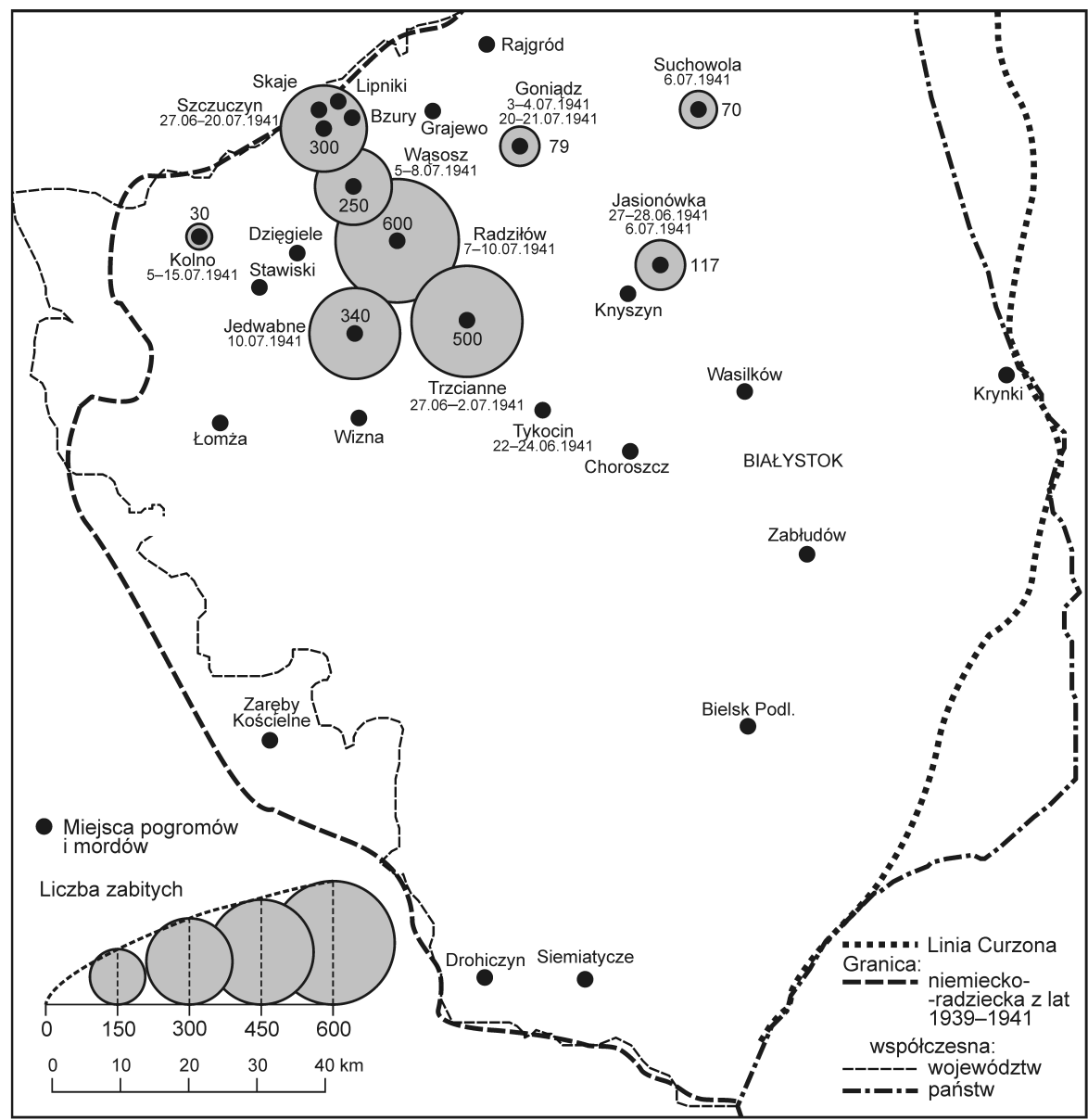

Ryc. 2. Wybrane miejsca zbiorowych mordów ludności żydowskiej, dokonanych przez polskich chrześcijan na Podlasiu i wschodnim Mazowszu w czerwcu i lipcu 1941 r. Źródło: opracowanie własne

Sąsiedzi, sięgając do genezy dokonywanej wtedy czystki etnicznej, przypisywali Żydom prokomunistyczną postawę oraz kolaborację z radzieckim okupantem, mającą wyrażać się w ich „nadreprezentatywności” w strukturach lokalnej administracji. Jednak wbrew stereotypowi głoszącemu, że polityka władz radzieckich - deklarujących hasła równouprawnienia i walki z wszelkimi przejawami nienawiści na tle narodowościowym - uzyskała powszechną aprobatę społeczności żydowskiej, reprezentacja Żydów przyjętych do struktur siłowych wcale nie była, jak szacuje A. Żbikowski (2006, s. 235-237), liczna, a zsyłki w głąb Związku Radzieckiego obejmowały ich w proporcjonalnie większym stopniu niż pozostałą ludność. 
Niemiecka polityka na nowo zdobytym terytorium zakładała inicjowanie aktów zbiorowej przemocy wobec jego żydowskich mieszkańców. W działaniach tych miała uczestniczyć miejscowa ludność, inspirowana przez politycznych aktywistów o antykomunistycznych poglądach, zainteresowanych zdławieniem wrogiej hitleryzmowi ideologii oraz zdeterminowanych do rozprawienia się z $\dot{Z} y-$ dami, postrzeganymi jako jej podstawowe zaplecze. Kluczowe znaczenie, jakie w wywoływaniu zajść przypisywano Polakom, wynikało m.in. z wyrażanego przez nich nierzadko negatywnego stosunku do ludności żydowskiej oraz chęci przejęcia należącego do niej mienia ${ }^{7}$. Wśród sprawców pogromów byli zarówno mieszkańcy tych ziem, jak i kontrolujący je przedstawiciele władz niemieckich, przy czym skala uczestnictwa każdej ze stron była warunkowana lokalnie, w zależności od miejscowości objętej antyżydowskim terrorem.

Katalizatorem eksplozji kolektywnej przemocy były pacyfikacyjne działania stosunkowo niedużych niemieckich formacji policyjnych na zapleczu przesuwającego się na wschód frontu ${ }^{8}$. Nie one jednak decydowały - zdaniem A. Żbikowskiego (2006, s. 236-239) - o jej przyczynie, podobnie zresztą jak niewiele wspólnego $\mathrm{z}$ eskalacją wystąpień antyżydowskich miały doświadczenia wyniesione przez polskie społeczeństwo z blisko dwuletniej okupacji radzieckiej ${ }^{9}$. Pogromy były przede wszystkim eksplozją narastającego od kilkudziesięciu lat antagonizmu, głównie ekonomicznego, podsycanego przez ideologów antysemityzmu, wywodzących się w dużej mierze z ugrupowań nacjonalistycznych, ale też i z hierarchii Kościoła katolickiego (Żbikowski 2006, s. 236-239, Rykała, Wosiak 2019). Do ich wybuchu w lecie 1941 r. przyczyniła się wprawdzie niemiecka inspiracja, jednak nie miała ona pierwszoplanowego znaczenia. Stacjonowanie niemieckich służb (wojska i policji), choć bardzo sprzyjało eskalacji agresji wobec Żydów, różniło się znacząco od metodycznego działania z sierpnia i września tego samego roku, które przybrało charakter ludobójczych „akcji” (Żbikowski 2006, s. 238, 222-224).

Jednym z wielu przypadków eksplozji zbiorowej agresji antyżydowskiej - z pewnością najwnikliwiej zbadanym, a w związku z tym najbardziej emblema-

${ }^{7}$ Źródło tych postaw osadzone było - jak to ujął A. Żbikowski (1992, s. 7) - w wielowiekowym systemie wzajemnych odniesień, wszechstronnych kontaktów i wzajemnej obserwacji.

${ }^{8}$ Niemieckie grupy operacyjne, grając - jak podkreślał S. Datner (1966, s. 19) - na najniższych instynktach, inicjowały niekiedy wybuchy ,gniewu ludu”, a ponadto dostarczały broni oraz udzielały wskazówek, same jednak nie biorąc ,udziału w rzezi”.

${ }^{9}$ Niektóre wydarzenia jednostkowe, zdaniem A. Żbikowskiego (1992, s. 7), musiały być jednak na tyle ważkie, że włączone w ,antysemicko zorientowany system wyobrażeń społecznych”, uległy generalizacji w zbiorowej świadomości. 
tycznym - był pogrom w Jedwabnem, do którego doszło 10 lipca 1941 r. (ryc. 3). W obecności kilku niemieckich żołnierzy, zaangażowanych w pomoc przy wyłapywaniu żydowskich mieszkańców, polscy sąsiedzi spędzili Żydów na rynek, gdzie poddali ich biciu (w którego wyniku kilku zmarło) oraz zmusili do wykonywania prac porządkowych. Następnie zgromadzili co najmniej $300 \mathrm{z}$ nich w stodole, którą następnie podpalili (Datner 1966, s. 20-23, Wroniszewscy 1988, s. 8-9, Żbikowski 1992; więcej na ten temat w: Gross 2000, Bikont 2004).

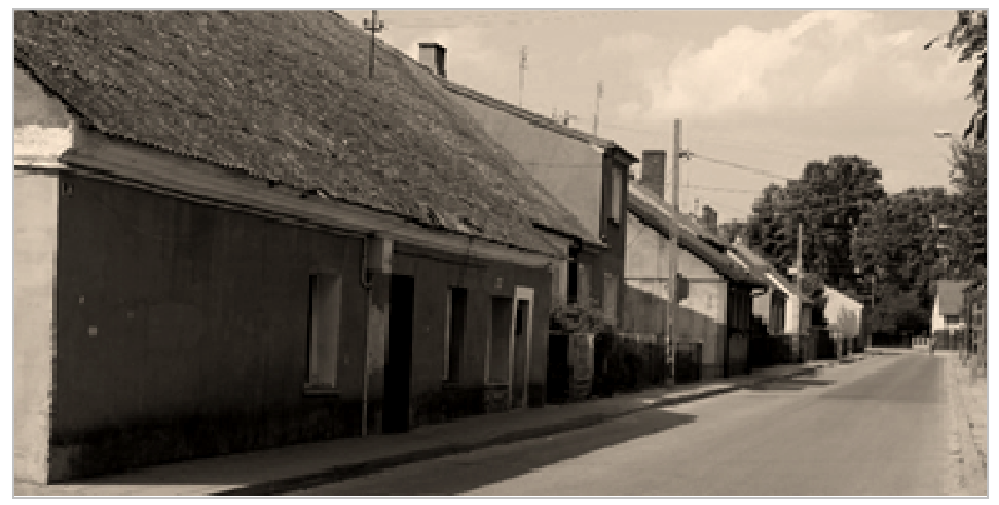

Ryc. 3. Jedwabne - miasto zbiorowego mordu Żydów, dokonanego przez ich polskich sąsiadów w lipcu 1941 r.

Źródło: fot. A. Rykała

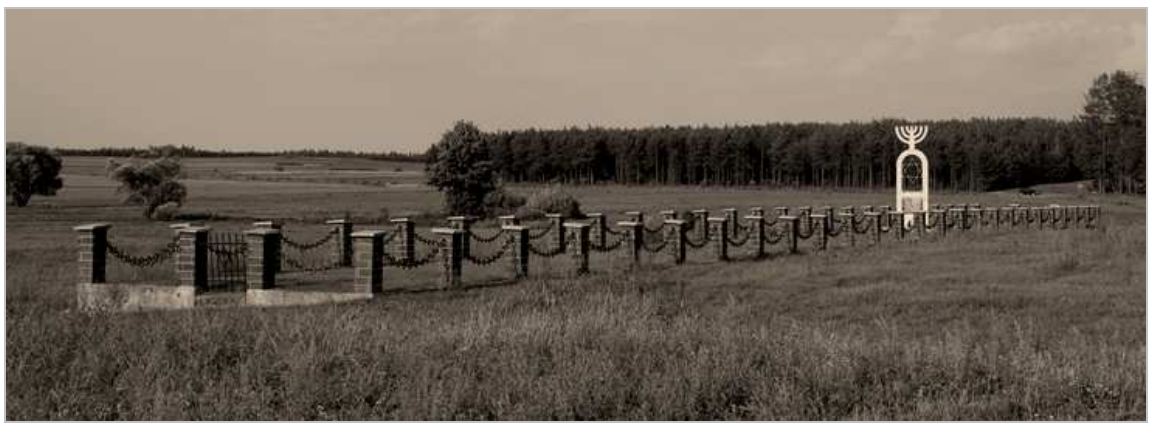

Ryc. 4. Wąsosz - miejsce wymordowania przez polskich chrześcijan niemal wszystkich żydowskich współmieszkańców po wycofaniu się wojsk radzieckich.

Zbiorowa mogiła ofiar pogromu

Źródło: fot. A. Rykała

Kilka dni wcześniej, 5 lipca 1941 r., z inspiracji Niemców, choć rękami Polaków, głównie zwerbowanych członków policji pomocniczej, dokonano pogromu w Wąsoszu (ryc. 4). W trakcie tego wydarzenia wielu Żydów zraniono przy uży- 
ciu prymitywnych narzędzi (siekier, wideł), w rezultacie wymordowano niemal całą miejscową ludność żydowską (ok. 250 osób) (Datner 1966, s. 20-23, Żbikowski 2002, s. 169-172, Milewski 2002, s. 87-112, Dmitrów 2002, s. 321-350, Monkiewicz 1989, s. 346).

Po Wąsoszu fala antyżydowskiego terroru bardzo szybko (7 lipca) dotarła m.in. do Radziłowa (ryc. 5). W trwającym trzy dni pogromie - poprzedzonym zainicjowaną przez Niemców 25 lipca 1941 r. akcją niszczenia zwojów Tory i upokarzania Żydów (m.in. golenie im bród) - miejscowi Polacy, korzystając z przyzwolenia niemieckich żandarmów, spędzili większość żydowskich sąsiadów do stodoły i tam ich spalili. Pozostałych wyłapano i zabito w inny sposób. Szacuje się, że zamordowano wówczas 600 Żydów (Datner 1966, s. 20-23, Żbikowski 2002, s. 231-259, Milewski 2002, s. 87-112, Dmitrów 2002, s. 321-350, Monkiewicz 1989, s. 346).

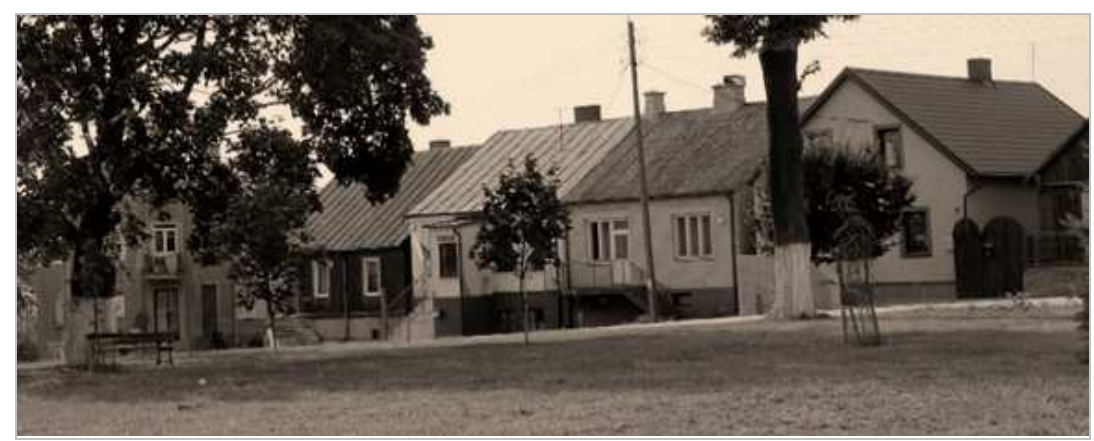

Ryc. 5. Radziłów - miasto spalenia żydowskich mieszkańców przez ich polskich sąsiadów, którego preludium było upokarzanie Żydów przez Niemców Źródło: fot. A. Rykała

Poza wymienionymi miejscowościami fala pogromów w pierwszych dniach okupacji niemieckiej objęła również m.in. Goniądz, Grajewo, Jasionówkę (dwukrotnie), Kolno, Suchowolę, Szczuczyn, Stawiska, Trzcianne. Do mordów o charakterze zbiorowym czy rozstrzeliwań pojedynczych ludzi dochodziło - zdaniem S. Datnera (1966) - niemal we wszystkich skupiskach żydowskich na Podlasiu i we wschodniej części Mazowsza.

Po nagłośnieniu mordu w Jedwabnem, głównie za sprawą książki J.T. Grossa (2000) oraz toczonej wokół niej ogólnopolskiej dyskusji ${ }^{10}$, dokonano zmiany

${ }^{10}$ Pokłosiem rozpętanej wówczas debaty były kolejne fundamentalne dzieła poświęcone tej tematyce, np. P. Machcewicz, K. Persak (red. 2002), A. Bikont (2004). Przed publikacją Sąsiadów, jak i po ich wydaniu, przebieg aktów kolektywnego terroru w Jed- 


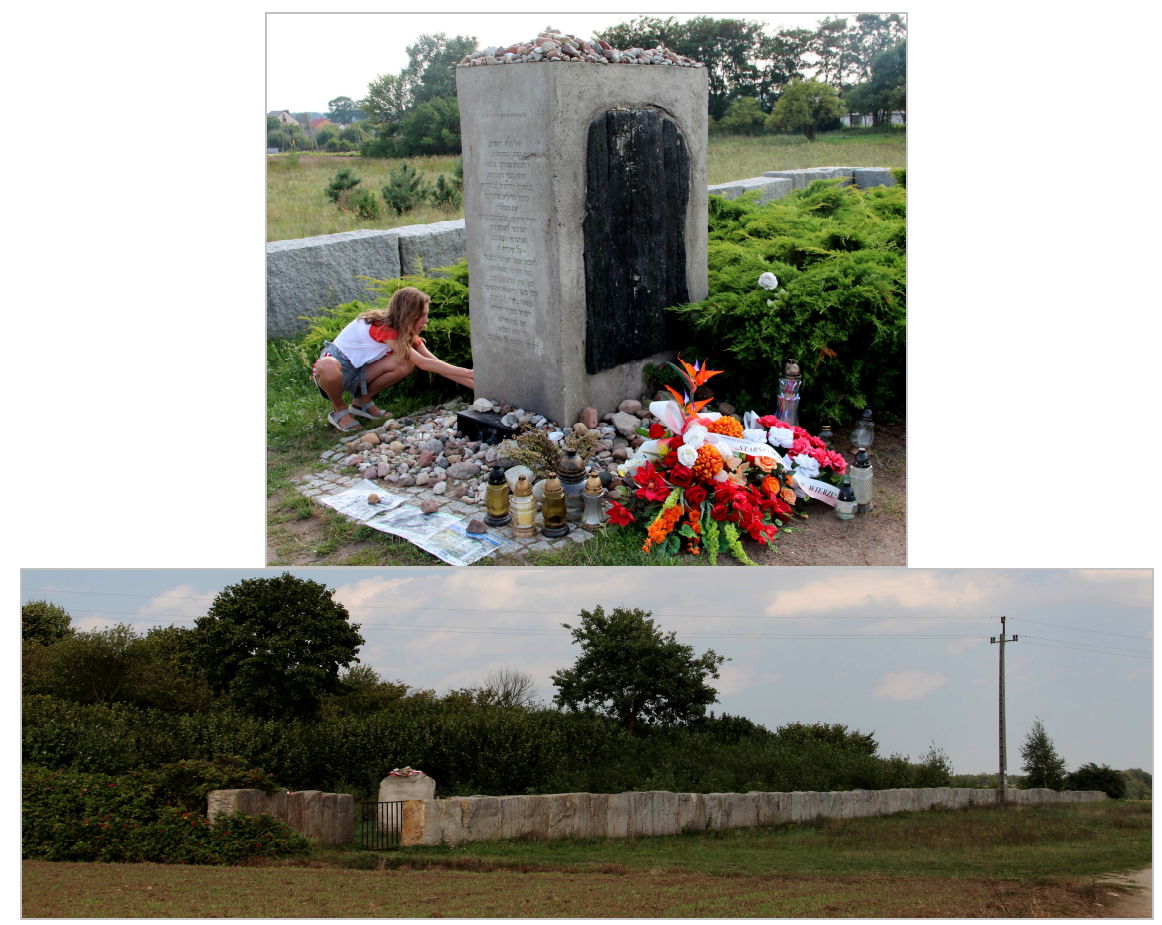

Ryc. 6 i 7. Pomnik upamiętniający zamordowanych (w wyniku spalenia) żydowskich mieszkańcow Jedwabnego, postawiony w miejscu po nieistniejącej już stodole (6). Znajdujący się w tym mieście cmentarz żydowski, na którym spoczywają m.in. pozostali Żydzi zamordowani 10 lipca 1941 r. (7) Źródło: fot. A. Rykała

wabnem i w innych miejscowościach na Białostocczyźnie i w Łomżyńskiem opisali m.in.: S. Datner (1966), który jako pierwszy podjął próbę przełamania milczenia wokół antyżydowskiej przemocy w lipcu 1941 r., D. i A. Wroniszewscy (1988) - podkreślający zbrodnie polskich sąsiadów i przywołujący relacje o współudziale jedwabińskich Żydów w organizowaniu transportów wywożących Polaków na Sybir, W. Monkiewicz (1989) - obarczający Niemców za mordy ludności żydowskiej w wymienionym okresie, A. Żbikowski (1992), A. Kaczyński (2000a, 2000b), T. Strzembosz (2001), A. Sułek (2001), J.T. Gross (2002). Kilkanaście lat po nastąpieniu apogeum dyskusji wywołanej Strachem ukazała się (w 2015 r.) - poświęcona wyjaśnieniu genezy i przebiegowi wydarzeń z lipca $1941 \mathrm{r}$. - książka M. Tryczyka Miasta śmierci. Sasiedzkie pogromy Żydów. Pozycja ta doczekała się kilku krytycznych recenzji, m.in. K. Persaka (2016), N. Aleksiun (2016) - samych w sobie będących studiami odsłaniania mechanizmów zajść pogromowych - w których zarzucono autorowi zbyt powierzchowne potraktowanie problemu zbrodni sąsiedzkiej oraz liczne błędy w interpretacji materiału źródłowego. Ambicja wyjścia poza wąskie grono specjalistów i odkrycia przed szerszą publicznością zagadnienia współudziału Polaków w zbrodni na Żydach przyświecała S. Zgliszczyńskiemu (2013), autorowi opracowania Jak Polacy Niemcom Żydów mordować pomagali. 
tablicy upamiętniającej wymordowanych żydowskich mieszkańców miasta. Widniejący na niej wcześniej napis, zafałszowujący przebieg wydarzeń („Miejsce kaźni ludności żydowskiej. Gestapo i żandarmeria hitlerowska spaliła żywcem 1600 osób 10.VII.1941"), ustąpił miejsca - przy okazji uroczystości odsłonięcia nowego pomnika - sentencji: „Pamięci Żydów z Jedwabnego i okolic, mężczyzn, kobiet, dzieci, współgospodarzy tej ziemi, zamordowanych, żywcem spalonych w tym miejscu 10 lipca 1941 r. Jedwabne 10 lipca 2001 r." (ryc. 6 i 7). Wyrażona bez niedomówień prawda o pogromie - a zwłaszcza jego głównych sprawcach - wciąż więc nie może doczekać się utrwalenia na kamieniu z imitacją spalonych drzwi jedwabińskiej stodoły.

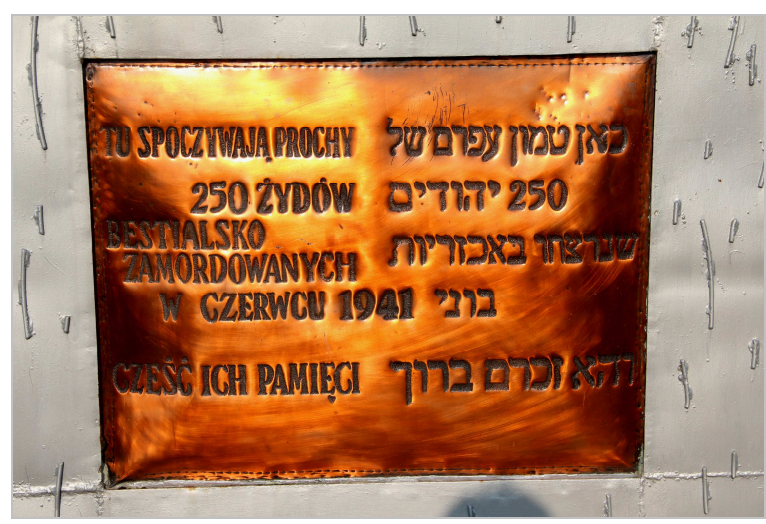

Ryc. 8. Tablica na pomniku upamiętniającym miejsce pochówku ofiar pogromu w Wąsoszu Źródło: fot. A. Rykała

W Wąsoszu natomiast nie znajdzie się żadnej informacji o wymordowaniu przez polskich oprawców niemal całej miejscowej ludności żydowskiej. Na tablicy umieszczonej na zbiorowej mogile ofiar pogromu widnieje napis: „Tu spoczywają prochy 250 Żydów, bestialsko zamordowanych w czerwcu $1941 \mathrm{r}$. Cześć ich pamięci” (ryc. 8). Mimo braku odwagi do ujawnienia przynależności etnicznej czy osadzenia terytorialnego sprawców pogromu, należy dostrzec - co może zabrzmi nieco cynicznie - i tak pewien postęp w stosunku do kłamstwa, którym raczono odwiedzających to miejsce w okresie Polski Ludowej i tuż po zmianie ustroju. Do $1995 \mathrm{r}$. - tj. do momentu usunięcia przez wąsoszan starego pomnika - przekaz na tablicy upamiętniającej miejsce masowej zbrodni sprowadzał się do słów: „Tu spoczywają Żydzi zamordowani przez faszystów”11.

${ }^{11}$ Z Przewodnika po upamiętnionych miejscach walk i męczeństwa; lata wojny 19391945, wydanego pod koniec Polskiej Rzeczypospolitej Ludowej (w 1988 r.), o Wąsoszu 
Miejscem pamięci o kaźni, której dokonali polscy chrześcijanie na 600 żydowskich współmieszkańcach, nie stał się również Radziłów. Na pomniku upamiętniającym ich męczeństwo wciąż widnieje inskrypcja: „W sierpniu 1941 r. faszyści zamordowali 800 osób narodowości żydowskiej, z tych 500 osób spalili w stodole. Cześć ich pamięci" (fot. 9 i 10). W odruchu bezsilności wynikającej z niezmienności stanowiska odpowiednich urzędów i władz w sprawie informacji umieszczonej na tablicy, przedstawiciele warszawskiej Gminy Wyznaniowej Żydowskiej ustawili w 2011 r. tablicę plastikową własnego autorstwa, która miała przywrócić prawdę o sprawcach, dacie i przebiegu zajść w Radziłowie. Napis pozostawiony przez tę delegację - zdjęty po niedługim czasie i zastąpiony cytatem z wypowiedzi Jana Pawła II - głosił, że:

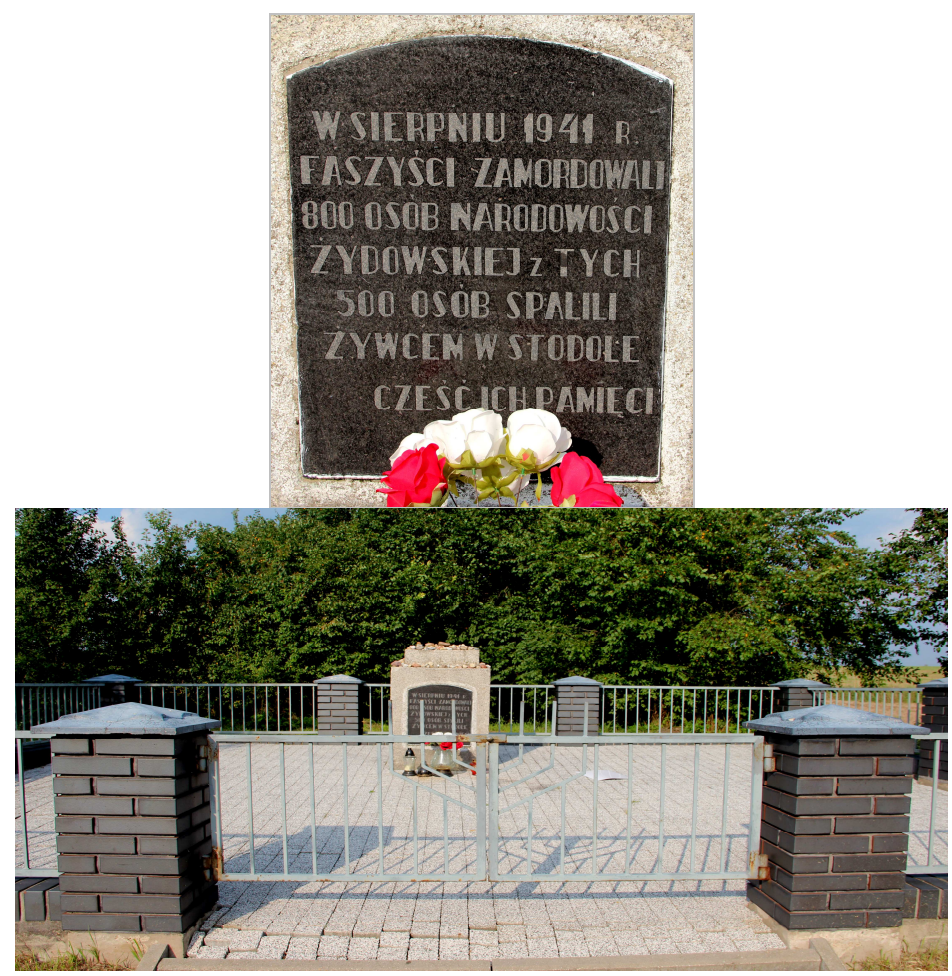

Ryc. 9 i 10. Tablica (9) na pomniku upamiętniającym miejsce pochówku Żydów zamordowanych przez ich sąsiadów chrześcijan w Radziłowie (10) Źródło: fot. A. Rykała

można się dowiedzieć tyle, że „w sierpniu 1941 r. 250 Żydów” zostało rozstrzelanych przez żołnierzy Wehrmachtu (s. 441), natomiast przy wzmiance o płycie na miejscu kaźni w Szczuczynie pojawia się informacja, że w tym samym czasie ,faszyści bestialsko zamordowali tu 600 Żydów" (Czubryt-Borkowski 1988, s. 438). 
W dniach od 7 do 9 lipca 1941 r. w Radziłowie zostało zamordowanych około ośmiuset żydowskich mieszkańców, w tym około pięciuset zostało żywcem spalonych w stodole. Zbrodni dokonali polscy współbracia - sąsiedzi. Pamięci żydowskich mieszkańców Radziłowa. Żydzi polscy. Niech dusze ich będą związane W węzeł życia wiecznego ${ }^{12}$.

Rozpatrując zagadnienie przemocy antyżydowskiej pod kątem miejsc upamiętniających jej ofiary i sprawców, moc, sankcjonowaną prawnie, zachowują więc nierównoprawne relacje większości z mniejszością. Dominujący w nich naród lub - inaczej rzecz ujmując - większość narodu polskiego (wszystkich Obywateli Polskich) narzuca jego mniejszości odpowiadający tej pierwszej grupie typ narracji, wykorzystując do tego przywilej decydowania o polityce i działaniach podległych sobie organów państwowych ${ }^{13}$, w tym również lokalnych samorządów ${ }^{14}$.

\footnotetext{
${ }^{12}$ https://sztetl.org.pl (15.10.2018).
}

13 Głównym organem państwowym inicjującym i koordynującym prace na rzecz upamiętniania historycznych wydarzeń, miejsc i postaci w dziejach walk i męczeństwa narodu polskiego zarówno w kraju, jak i za granicą oraz miejsc zmagań i martyrologii innych grup narodowościowych na terytorium Polski od 1917 r. do 1990 r. jest Instytut Pamięci Narodowej (IPN) - Komisja Ścigania Zbrodni przeciwko Narodowi Polskiemu. Przejął te obowiązki 1 sierpnia 2016 r., na mocy ustawy z 29 kwietnia 2016 r. o zmianie ustawy o IPN oraz innych ustaw, od zlikwidowanej wówczas, a działającej od 1988 r., Rady Ochrony Pamięci Walk i Męczeństwa, będącej jedyną organizacją państwową zajmującą się kultywowaniem pamięci o walce i męczeństwie Polaków. Bezpośrednio za inicjowanie działań w celu roztoczenia opieki nad miejscami walk i męczeństwa oraz trwałe upamiętnianie faktów, wydarzeń i postaci, które z tymi wydarzeniami miały związek, odpowiada z ramienia IPN Biuro Upamiętniania Walk i Męczeństwa.

${ }^{14}$ Znamiennym przykładem selektywnego podchodzenia do kwestii oznaczenia w przestrzeni lokalizacji naznaczonych bohaterskim czynem lub cierpieniem może być akcja „Tablice pamięci”, przedsięwzięta przez Ministerstwo Kultury i Dziedzictwa Narodowego (MKiDN) - drugą, obok IPN, instytucję zajmującą się kultywowaniem pamięci o walce i męczeństwie narodu polskiego - sam Instytut oraz Polską Grupę Energetyczną (PGE). Idea tego przedsięwzięcia sprowadza się do uzupełniania i popularyzacji informacji historycznych poprzez umieszczanie tablic $\mathrm{w}$ językach polskim i angielskim $\mathrm{w}$ miejscach pamięci z okresu drugiej wojny światowej. Projekt, obejmujący m.in. rewitalizację takich ekspozycji, ma - w opinii jednego z patronów akcji, ministra kultury - przywracać ,,prawdę historyczną o wydarzeniach drugiej wojny światowej”. Gdy zabraknie świadków tamtych historii - głosił prezes IPN - te tablice „będą wołać, będą krzyczeć”. „Chcemy - jak dodał - żeby ten krzyk był również zrozumiały dla tych, którzy tutaj do Polski przybędą" (W Warszawie... 2018). W kontekście słusznego skądinąd apelu, chce się jednak zwrócić uwagę na „krzyk” dobiegający z - nieprzywracających „,prawdy historycznej” - tablic poświęconych Żydom pomordowanym przez reprezentantów narodu polskiego na Podlasiu, wschodnim Mazowszu i w innych regionach kraju, na który przedstawicielstwa wspomnianych instytucji pozostają głuche. 
Efekt żonglowania nazewnictwem swoją kontrowersyjną, w opinii autora, odsłonę znalazł również - choć już w pewnym oddaleniu czasowym i przestrzennym od przywołanych aktów bestialstwa - np. na tablicy upamiętniającej miejsce po pierwszym, założonym w 1811 r., nieistniejącym już cmentarzu żydowskim w Łodzi. Z zamieszczonej na tej tablicy informacji można się dowiedzieć o sprawcach likwidacji nekropolii, przy czym etniczna proweniencja została przypisana tylko części z nich (Niemcom). Pozostałych utożsamiono - tak jakby składającym się nań identyfikacjom nie towarzyszyła jakakolwiek narodowościowa grupa odniesienia - z funkcjonariuszami systemu politycznego (komunistami), za których panowania to najstarsze miejsce pochówku łódzkich Żydów ostatecznie zamknięto (w 1949 r.) (ryc. 11 i 12). Odtworzenie pamięci tego miejsca, które - poza charakterem informacyjnym o jego dawnym przeznaczeniu - może być podstawą do kształtowania się tożsamości lokalnej, wykorzystane zostało więc również do legitymizacji porządku politycznego ustanowionego w imię większości narodowej.

STARY CMENTARZ PRZY ULICY WESOKE, ZALOZONY 4 KWIETNIA 1811 ROKU

CZYNNY DO 1922 ROKU. CZEŚCIOWO ZDEWASTOWANY PRZEZ NIEMCÓW

W 1942 ROKU, ZNISZCZONY PRZEZ WZADZE KOMUNISTYCZNE W LATACH 1949-1954 POCHOWANO TU 12 TVSIECY OSOB
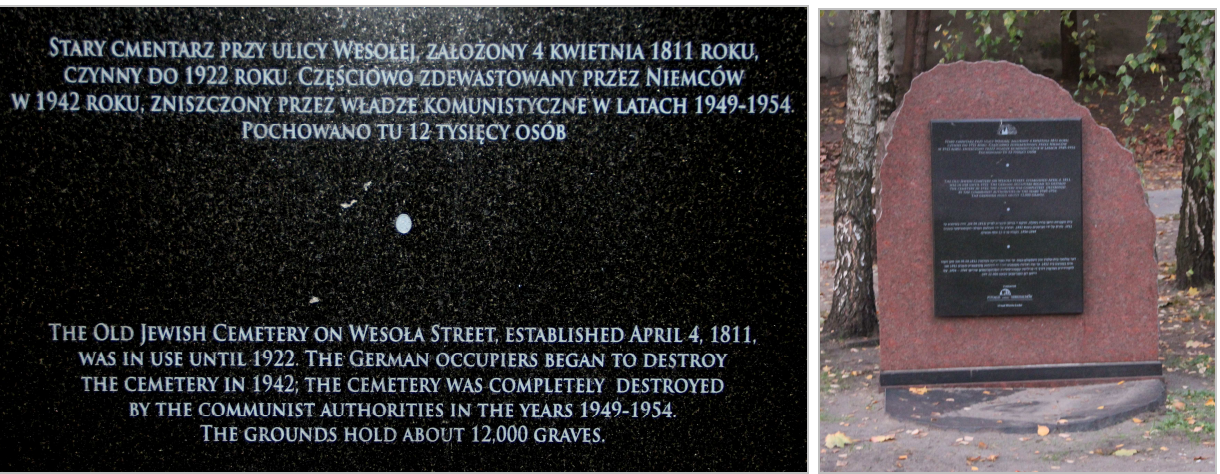

Ryc. 11 i 12. Tablica (11) na pomniku upamiętniającym stary cmentarz żydowski w Łodzi (12)

Źródło: fot. A. Rykała

\section{Zbrodnie na Żydach na terenach opuszczonych przez Niemców - przyczyny oraz uwarunkowania przestrzenne, polityczne i społeczne}

Akty przemocy antyżydowskiej - z których wiele z czasów wojny wciąż nie doczekało się $\mathrm{w}$ przestrzeni upamiętnienia zawierającego chociażby podstawową prawdę o ich przebiegu - postępowały sukcesywnie, o czym sygnalizowano, wraz z wyzwalaniem kolejnych ziem spod okupacji niemieckiej. „Wypadki mordów, szczególnie licznych $\mathrm{w}[\ldots]$ lubelskiem i rzeszowskiem przenoszą się $[\ldots]-$ na co 
zwracał uwagę Referat do Spraw Pomocy Ludności Żydowskiej przy Prezydium Rady Ministrów w kwietniu 1945 r. - na teren innych województw jak: kieleckie i łódzkie" ${ }^{, 15}$.

Tabela 1. Przemoc wobec Żydów w kwietniu 1945 r. na terenach wyzwolonych spod okupacji niemieckiej

\begin{tabular}{|l|c|c|c|}
\hline \multirow{2}{*}{ Województwo } & \multicolumn{3}{c|}{ Liczba } \\
\cline { 2 - 4 } & napadów & zabitych & rannych \\
\hline Lubelskie & 2 & 8 & - \\
\hline Warszawskie & 2 & 4 & 2 \\
\hline Kieleckie & 5 & 18 & 1 \\
\hline Rzeszowskie & 1 & - & - \\
\hline Krakowskie & 1 & 2 & 7 \\
\hline Razem & 11 & 32 & \\
\hline
\end{tabular}

Źródło: opracowanie własne na podstawie AAN, MAP, DP, WN 786. Pismo naczelnika Wydziału Społeczno-Politycznego MAP do Ministerstwa Bezpieczeństwa Publicznego, z 29 września 1945 r., w sprawie mordów i rabunków dokonywanych na obywatelach polskich narodowości żydowskiej.

W marcu 1945 r. napadnięto 117 Żydów: w województwie białostockim - 21, lubelskim -33 , warszawskim -35 , rzeszowskim -23 i kieleckim -5 . W wyniku tych napaści 108 osób poniosło śmierć, natomiast 9 zostało rannych. W następnym miesiącu w województwach lubelskim, warszawskim, kieleckim, rzeszowskim i krakowskim dokonano 11 napadów, w których zamordowano 32 osoby, a 7 raniono (tab. 1) ${ }^{16}$. Z kolei w miesiącu zakończenia wojny m.in. w Lubelskiem odnotowano dwie napaści i tyluż zabitych, w Łódzkiem - napad o charakterze rabunkowym i osiem ofiar śmiertelnych ${ }^{17}$. W opinii dyrektora Departamentu Politycznego Ministerstwa Administracji Publicznej (MAP), wyrażonej w marcu 1945 r., „wypadki szykan, a nawet morderstw” prowadzily do „wybitnego pogorszenia nastrojów wśród ludności żydowskiej, pesymizmu i nieufności wobec władz"18.

15 AAN, Urząd Rady Ministrów (URM), Biuro Prezydialne 5/17, Dziesiąte sprawozdanie (za kwiecień 1945 r.) z działalności Referatu dla Spraw Pomocy Ludności Żydowskiej przy Ministerstwie Pracy i Opieki Społecznej.

${ }^{16}$ AAN, MAP, DP, WN 786, Pismo naczelnika Wydziału Społeczno-Politycznego MAP do Ministerstwa Bezpieczeństwa Publicznego, z 29 września 1945 r., w sprawie mordów i rabunków dokonywanych na obywatelach polskich narodowości żydowskiej.

${ }^{17}$ Ibidem.

18 AAN, MAP, DP, WN, sygn. 786, Pismo Departamentu Politycznego MAP do siedmiu wojewodów, z 21 III 1945 r. Do jednego z pierwszych powojennych aktów 
Jedno z głównych źródeł przemocy antysemickiej tkwiło w - będących naturalnym odruchem - powrotach ocalałych do swoich przedwojennych miejsc zamieszkania. Następowały one $\mathrm{z}$ wielu powodów, $\mathrm{np} . \mathrm{z}$ tęsknoty do rodzinnego domu, chęci odzyskania pozostawionego mienia, rozeznania się w sprawie losów członków rodziny, pozostałych bliskich. Wielu powracających nie mogło jednak przekroczyć progu swoich mieszkań, gdyż zajęli je nieżydowscy sąsiedzi. Znaczna część majątku należącego do ocalałych Żydów, w tym ruchomości (m.in. bardziej lub mniej cenne przedmioty oddane w zaufaniu na przechowanie), znalazła się w polskich rękach już w czasie wojny ${ }^{19}$. Stając wobec niemożności odzyskania zagrabionego mienia, Żydzi opuszczali na ogół swoje przedwojenne miejsca zamieszkania - bardzo często przymuszeni do tego przez lokalną społeczność - i udawali się do miejscowości, w których przebywali członkowie ich rodzin lub tworzyły się większe skupiska żydowskie. Wrogi stosunek do dawnych właścicieli, przejawiany przez nowych, nieprawowitych lokatorów, rodził też sytuacje konfliktowe. Stawały się one niejednokrotnie skrajnie niebezpieczne, przybierając formę bezpardonowych ataków na Żydów, które kończyły się nawet ofiarami śmiertelnymi.

przemocy kolektywnej, który wywołała plotka o mordzie rytualnym, dokonanym na kilkuletniej dziewczynce, doszło 12 czerwca 1945 r. w Rzeszowie. Agresja thumu skierowana w stronę ludności żydowskiej oraz jej masowe aresztowania spowodowały wyjazd zdecydowanej większości z ok. 1 tys. miejscowych Żydów. W konsekwencji działalność zawiesił założony kilka miesięcy po wycofaniu się wojsk niemieckich Okręgowy Komitet Żydowski w tym mieście. Oficjalnie wznowił ją dopiero 14 listopada 1945 r., wraz z przybyciem na początku tego miesiąca kolejnej, kilkunastoosobowej grupy żydowskich osadników (AŻIH, CKŻP, Wydział Organizacyjny, sygn. 34; AAN, URM, Biuro Prezydialne 5/17, Dwunaste sprawozdanie (za czerwiec 1945 r.) z działalności Referatu dla Spraw Pomocy Ludności Żydowskiej przy Ministerstwie Pracy i Opieki Społecznej).

${ }^{19}$ Oprócz sąsiadów, którzy rozkradali majątki żydowskie jeszcze w okresie przebywania ich właścicieli w miejscu zamieszkania (na ogół tuż przed wywiezieniem do obozów), byli i tacy, którzy wprowadzili się do nieruchomości i przejęli znajdujące się w nich mienie już po wysiedleniu Żydów. Niektórzy z nowych lokatorów nie wyzbyli się empatii wobec prawowitych posesjonatów; zamieszkali w nieswoich domach ,z szacunkiem, z żałobą w sercu". Pochodząca z Ćmielowa 83-letnia autorka owych słów, okres przejmowania opuszczonego mienia w tym mieście opisała w następujący sposób: „Jak Żydów wywieźli, byliśmy przerażeni. Nagle niemalże cały rynek opustoszał. Nastała straszna cisza, człowiek się bał wyjść z domu i jeden do drugiego mówić. [...] Pamiętam te domy puste, wymarłe wszystko. Nie do opisania pustka, strach, jak się patrzyło w ich stronę. Niedługo do taty przyszedł znajomy [...] i powiedział, że dom i piekarnia po Junkielu stoi pusta, żeby ją przejął, nim ktoś inny to zrobi. [...] Wiedziałam, że to szansa na lepsze życie" (Kaleta 2018, s. 18-19). 
Na tle przypadków konfiskaty i grabieży mienia żydowskiego, po które zwracali się prawowici właściciele lub ich krewni, wzmagały się nastroje antysemickie, wzmocnione wpływem niemieckiej propagandy ${ }^{20}$. Wojna, zdaniem A. Skibińskiej (2011, s. 40-41), w najmniejszym stopniu nie przyczyniła się do złagodzenia czy zdyskredytowania uprzedzeń Polaków wobec Żydów. Żywotność antyżydowskich stereotypów okazała się trwała. Nie wzbudziła w społeczeństwie polskim współczucia dla ofiar Zagłady ani nie spowodowała poczucia solidarności z nimi (Skibińska 2011, s. 40-41). Część Polaków „tępienie Żydów” uznawała - jak dowodziła I. Hurwic-Nowakowska (1996, s. 140) - za postępowanie „dość naturalne”, będące kontynuacją „,wszczepionych [podczas okupacji - przyp. A.R.] wartości i pojęć”. Życie ocalałych po zakończeniu wojny „było w wielu sferach recydywą z okresu okupacji” (Skibińska 2011, s. 40-41). Nadal „czuli się wykluczeni, szykanowani, dyskryminowani, niechciani, a nawet znienawidzeni" (Skibińska 2011, s. 69). Kontynuację postępowania morderców z okresu wojny stanowiło wspomniane grabienie mienia ofiar. Żydzi ginęli - zdaniem A. Całej (2000, s. 169) - „bez wyraźnego powodu, dlatego tylko, że wciąż uważano ich za wyzutych spod prawa".

Do większości morderstw dochodziło w małych miastach, a nawet wsiach ${ }^{21}$. W połączeniu z ucieczką Żydów, którzy nie chcieli podzielić losu ofiar, wypadki te prowadziły, zwłaszcza we wschodniej Polsce, do zaniku wielu skupisk żydowskich.

Kolejną z przyczyn terroru był pozytywny odzew na głoszone przez część tzw. podziemia niepodległościowego hasło walki z ,żydokomuną" - stereotypem żywym w całym okresie międzywojennym, a „odmrażanym” (z różnym nasileniem) także podczas okupacji ${ }^{22}$. Geneza łączenia członków narodu żydowskiego w Polsce z komunistami tkwiła w zaangażowaniu się jeszcze przed wojną części środowiska politycznego reprezentującego Żydów w urzeczywistnianie idei światowego proletariatu, mające doprowadzić do uformowania się nowej klasy społecznej, wolnej od wszelkich form dyskryminacji. Liczną i znajdującą się na upośledzonej pozycji mniejszość, na dodatek pozbawioną wsparcia ze strony

${ }^{20}$ Mimo skrajnie trudnego pod względem materialnym położenia Żydów - często bezdomnych, na dodatek osamotnionych, wylęknionych, wyobcowanych, traktowanych i czujących się tak, jakby byli zbędni - wciąż powracał mit o ich niewyczerpanym bogactwie, stanowiący dodatkową motywację do zbrojnych napaści na nich.

21 Dopuszczanie się mordów przez chłopów, zwłaszcza małorolnych, jawi się nad wyraz tragicznie w obliczu przeprowadzanej reformy rolnej, której mieli być oni beneficjentami, zresztą tak jak całości zmian ustrojowych w Polsce.

${ }^{22}$ Więcej na temat związków Żydów z tą polityczną i ekonomiczną ideologią m.in. w: A. Grabski (2004, 2007), J. Nalewajko-Kulikov (2009), P. Śpiewak (2012), P. Kendziorek (2016). 
tzw. zagranicznej ojczyzny, na które mogły liczyć inne grupy o takim statusie, łączono w II Rzeczypospolitej z komunizmem niemal organicznie. Działo się tak, mimo że była to społeczność kulturowo i politycznie zróżnicowana, złożona $\mathrm{w}$ dużej mierze $\mathrm{z}$ wrogich komunizmowi środowisk religijnych czy socjalistycznych (takich jak Bund, dążący do powołania autonomii narodowo-kulturalnej dla Żydów w państwach zamieszkania), które system ten ze szczególną mocą zwalczał. Po wojnie stereotyp ten odżył wraz z dopuszczeniem Żydów, po raz pierwszy w polskiej historii, do stanowisk w administracji państwowej. Związany $\mathrm{z}$ awansem społecznym afirmatywny stosunek części społeczności żydowskiej do dokonujących się w Polsce zmian ustrojowych został wykorzystany (pod hasłem walki $\mathrm{z}$, żydokomuną") przez podziemie antykomunistyczne do inicjowania zbrojnych napaści na Żydów. Posądzenia ich o powszechne wsparcie dla pozbawionej legitymacji społecznej władzy, a zarazem rzekomo aktywne uczestnictwo w tworzeniu jej struktur przeniknęło do szerokiej opinii publicznej. Podatny grunt dla zakorzenienia się tego typu myślenia stworzyła jeszcze przed wojną napastliwa antyżydowska działalność i agitacja ugrupowań skrajnie narodowych (nacjonalistycznych, parafaszystowskich, faszystowskich), którym wtórowała spora część duchowieństwa i prasy katolickiej.

Za atakami na Żydów stali w dużej mierze spadkobiercy ideologii obozu narodowego, skupieni w organizacjach podziemia antykomunistycznego. Jedna z nich, Narodowe Siły Zbrojne (NSZ), już w czasie wojny (w 1942 r.) w sposób dość klarowny wyrażała swoje stanowisko w kwestii ginącego narodu i Polaków wykazujących się odwagą niesienia mu pomocy: „Należy napiętnować tych, którzy chcą ukrywać między sobą Żydów i ogłosić ich zdrajcami sprawy polskiej. Gdy każdy Polak wie, że w odrodzonej Polsce, tak dla Niemca, jak i dla Żyda miejsca nie ma" (za: Grabowski 2008, s. 88) ${ }^{23}$. Polskę bez Żydów widziała również część poakowskiego podziemia. W ulotce kolportowanej przez Wolność i Niezawisłość (WiN) stawiano retorycznie brzmiące pytania: „Polacy! Chcecie dalszej okupacji Polski? [...] Chcecie by inteligencja Polska zastąpiona została przez żydów? Chcecie by polski robotnik był niewolnikiem władz sowiecko-komunistycznożydowskich?" (za: Cała, Datner-Śpiewak 1997, s. 36$)^{24}$.

Z przyczyn czysto politycznych, czyli z potrzeby przeciwdziałania zajmowaniu stanowisk w różnych resortach komunistycznej władzy (zwłaszcza siłowych), Żydów zabijano - jak wynika z badań A. Całej (2000) - stosunkowo rzadko; głównie takie motywacje leżały np. u podstaw mordu partyzantów, którzy wstąpili do

\footnotetext{
${ }^{23}$ Fragment tekstu z „Propagandy Centralnej”, organu NSZ.

${ }^{24}$ Ulotka WiN była rozpowszechniania w okresie poprzedzającym referendum czerwcowe w $1946 \mathrm{r}$.
} 
Urzędu Bezpieczeństwa (Cała 2000), czy byłego pracownika służby bezpieczeństwa w Lublinie, pozbawionego życia 19 marca 1946 r. ${ }^{25}$ Zbrodni, których podłoże stanowiła chęć rozprawienia się z osobami utrwalającymi nowy system, dokonywano - jak można wnioskować - na pojedynczych, konkretnych osobach (Skibińska 2007, Żbikowski 2011; zob. też: Engel 1998). Częściej - gdy celem przemocy był rabunek lub niechęć do Żydów motywowana tzw. tradycyjnym antysemityzmem - umocowani w aparacie władzy stawali się ofiarami przypadkowymi.

Walka z ,żydokomuną” była więc dla części antykomunistycznego podziemia uniwersalnym zawołaniem do oczyszczenia ziem polskich z Żydów, do którego miały doprowadzić ich mordowanie lub zmuszenie do emigracji. Pod tym hasłem podpisywali się również nielegalni posiadacze żydowskiego mienia, mający na koncie zbrodnie przeciw prawowitym właścicielom. W ten sposób zdobywali alibi dla swojego postępowania oraz pozornie uspakajali nieczyste sumienie. Jak wynika ze sprawozdania Wydziału Narodowościowego Departamentu Politycznego MAP, od początku października 1945 r. do końca tego roku:

zginęło z rąk bandytów NSZ-u 38 Żydów [...]. Były wypadki, że bandyci zmasakrowali i obrabowali Żydów i nakazali im w przeciągu 24 godzin opuścić miejsce zamieszkania. W jednym wypadku po zamordowaniu Żydów pewna część mieszkańców obrabowała ich mieszkania ${ }^{26}$.

Paradoksalnie - biorąc pod uwagę dość powszechne przekonanie o uprzywilejowanej pozycji Żydów w nowym ustroju oraz zdominowaniu przez nich stanowisk $\mathrm{w}$ aparacie władzy ${ }^{27}$ - przemocy antyżydowskiej lub jej lekceważenia do-

${ }^{25}$ AAN, MAP, DP, WN, sygn. 787, Memoriał Wojewódzkiego Komitetu Żydowskiego w Lublinie, z 23 marca 1946 r., w sprawie bezpieczeństwa życia i mienia żydostwa polskiego.

${ }^{26}$ AAN, MAP, DP, WN, sygn. 787, Sprawozdanie Wydziału Narodowościowego Departamentu Politycznego MAP za okres od 1 października 1945 do 1 stycznia $1946 \mathrm{r}$.

${ }^{27}$ Podjęcie służby w UB, MO i wojsku przez Żydów czy osoby pochodzenia żydowskiego (w końcu to kwestia samookreślenia) mogło świadczyć o poczuciu zagrożenia ze strony nieżydowskiego otoczenia (Skibińska 2007, s. 572; zob. też: Kainer 1983, Kersten 1992, 1993, Paczkowski 2001). Obok swoistego schronienia resorty te zapewniały możliwość wpływu na bieg wydarzeń w kraju oraz ułatwiały dostęp do legalnej broni, przydatnej w obliczu napaści. Nie można też wykluczyć - co tylko wskazuje na złożoność motywów popychających ocalałych do pracy w organach siłowych - naturalnej chęci rozliczenia winnych poniżenia, krzywd i zbrodni, a niekiedy nawet doprowadzenia do jakiejś formy zadośćuczynienia czy dokonania zemsty. Zob. też: Libionka 2006. 
puszczali się przedstawiciele służb mundurowych (Urzędu Bezpieczeństwa, Wojska Polskiego), zobowiązani do zapewnienia ocalałym ochrony.

Referat do Spraw Pomocy Ludności Żydowskiej w lutym 1945 r. sprawozdawał, że „Milicja [...] nie tylko nie bierze w obronę Żydów przed napadami, jakie mają miejsce [w Dęblinie - przyp. A.R.], lecz wręcz przeciwnie, sama bierze aktywny udział w szykanowaniu ludności żydowskiej”28. W Bytomiu

funkcjonariusze Bezpieczeństwa Publ[icznego] z Chorzowa przeprowadzali rewizje osobiste na ulicy i w bramach w biały dzień zabierali co kto posiadał, a następnie odwiedzili jedno mieszkanie żydowskie pod wieczór, gdzie zabrali rzeczy oraz pieniądze należące do Repatriantów przybyłych z Rosji, oraz [...] zdemobilizowanych żołnierzy ${ }^{29}$.

W służbach powołanych w celu zapewnienia porządku i bezpieczeństwa, a zarazem odpowiedzialnych w sposób szczególny za utrwalanie nowego ustroju, miejsca dla siebie niejednokrotnie znaleźli ideowi spadkobiercy obozu narodowego, w tym obciążeni zbrodniami dokonanymi na Żydach w okresie wojny (Skibińska 2007, s. 573, Tokarska-Bakir 2018b, s. 4-6) ${ }^{30}$.

Z przejawami niechęci, a nawet wrogości Żydzi spotykali się również ze strony urzędników administracji terenowej wszystkich szczebli (Adelson 1993, s. 402, Pisarski 1997, s. 30) ${ }^{31}$. Najczęściej sprowadzały się do piętrzenia trudności w przydzielaniu mieszkań (będących w wielu przypadkach własnością występujących o nie) oraz zatrudnieniu $\mathrm{w}$ państwowych urzędach i przedsiębiorstwach ${ }^{32}$. Jak sprawozdawał w maju 1945 r. Referat do Spraw Pomocy Ludności Żydowskiej ${ }^{33}$ :

${ }^{28}$ AAN, URM, Biuro Prezydialne 5/17. Ósme sprawozdanie (za luty 1945 r.) Referatu dla Spraw Pomocy Ludności Żydowskiej dla Premiera Rządu Tymczasowego Rzeczpospolitej Polskiej, Edwarda Osóbki Morawskiego. Podobny stosunek do Żydów reprezentowały lokalne władze m.in. w Radomiu, Chełmie, Zwoleniu, Ostrowcu Swiętokrzyskim, Łukowie.

${ }^{29}$ AAN, MAP, DP, WN, sygn. 787. Odpis pisma WKŻ w Katowicach skierowanego 18 grudnia 1945 r. do Wojewódzkiego Urzędu Bezpieczeństwa publicznego w sprawie aktów antysemityzmu w województwie śląsko-dąbrowskim.

${ }^{30}$ Więcej o udziale funkcjonariuszy resortów siłowych w powojennej przemocy antyżydowskiej w kontekście analizy społecznych uwarunkowań przyczyn pogromu kieleckiego w: J. Tokarska-Bakir 2018a. Losom Żydów ukrywających się w czasie wojny w regionie kielecko-sandomierskim oraz powrotom na ten obszar ocalałych z Zagłady (z cezurą do pogromu kieleckiego) wspomniana autorka poświęciła pracę Okrzyki pogromowe. Szkice z antropologii historycznej Polski lat 1939-1946 (wydaną w 2012 r.).

${ }^{31}$ AAN, MAP, DP, WN, sygn. 786, 787; AAN, URM, Biuro Prezydialne 5/17.

${ }^{32}$ AAN, URM, Biuro Prezydialne 5/17.

33 AAN, MAP, DP, WN, sygn. 787, Pismo dyrektora Departamentu Politycznego MAP do Urzędu Wojewódzkiego w Kielcach, z 25 czerwca 1945 r. 
„W Jędrzejowie starosta [...] załatwia wszystkie sprawy żydowskie odmownie, podobnie w Chęcinach i Chmielniku. W Ostrowcu Miejska Rada Narodowa zażądała [od miejscowego komitetu żydowskiego - przyp. A.R.] skierowania wszystkich Żydów do pracy w kopalni”, natomiast w Krzczonowie w lutym tego roku częste były „łapanki uliczne na roboty wyłącznie tylko Żydów”34. Z kolei w Tarnowie Zarząd Miejski dopuszczał się poboru od żydowskich mieszkańców zaległości podatkowych ,z czasów okupacji niemieckiej, tj. za czas, kiedy powyżsi obyw[atele] byli w niemieckich obozach koncentracyjnych, a ich majątki były pod zarządem niemieckim. Interwencja u prezydenta miasta w tej sprawie była bezskuteczna" ${ }^{\natural 5}$. Bezpardonowemu zachowaniu urzędników administracji samorządowej i bezpieczeństwa publicznego towarzyszyły często słowna agresja i nakłanianie do zmiany miejsca pobytu ${ }^{36}$.

Żydów mordowano za to, że nimi byli, a pełnienie funkcji w strukturach nowej władzy, rabunek mienia żydowskiego i zapobieżenie odzyskaniu go przez ocalałych nie zamykały listy przyczyn przemocy antyżydowskiej. Niewyczerpanym źródłem uprzedzeń pozostawały przesądy religijne, w tym zwłaszcza legenda mordu rytualnego. Do jej średniowiecznej wersji (w której krew zamordowanego nie-Żyda miała posłużyć do wyrobu macy) dołączyła po wojnie jej ,zmodernizowana" - jak zauważa A. Żbikowski (2011, s. 72) - odmiana: krew dzieci chrześcijańskich miała być potrzebna do transfuzji dla wycieńczonych wojną Żydów (nie należy wykluczać, że pewna grupa uczestników pogromu kieleckiego dawała wiarę plotce o porwaniu i przechowywaniu kilkuletniego chłopca w celu dokonania na nim mordu rytualnego).

O fali przemocy wobec ludności żydowskiej niech świadczą wybrane przypadki mordów (ryc. 13). Jeszcze przed zakończeniem wojny, 11 lutego 1945 r., na wyzwolonym już spod okupacji niemieckiej obszarze, we wsi Rozalin niedaleko Baranowa, wymordowano trzyosobową rodzinę. Tyluż samo Żydów zabito 6 kwietnia tego roku w Kosowie Podlaskim. Wśród ofiar mordu byli: Hersz Siedlecki (30 lat), Icek Majdenberg (22 lata), Gita Jabłkowska (20 lat). Ciężko ranni zostali

${ }^{34}$ AAN, URM, Biuro Prezydialne 5/17, Ósme sprawozdanie (za luty 1945 r.) Referatu dla Spraw Pomocy Ludności Żydowskiej dla Premiera Rządu Tymczasowego Rzeczpospolitej Polskiej, Edwarda Osóbki Morawskiego.

35 AAN, MAP, DP, WN, sygn. 787, Odpis pisma Powiatowego Komitetu Żydowskiego w Tarnowie do CKŻP w sprawie działalności Komisji Kwaterunkowo-Budowlanej i wojska, $\mathrm{z}$ dn. 13 listopada $1945 \mathrm{r}$.

${ }^{36}$ AAN, MAP, DP, WN, sygn. 786, Pismo Departamentu Politycznego MAP do siedmiu wojewodów, z 21 III 1945 r.; AŻIH, CKŻP, Wydział Organizacyjny, sygn. 15. Chcących się osiedlić zastraszano groźbami niezidentyfikowanych, przybierających konspiracyjne nazwy grup. 
Rojza Flam (26 lat) i Lejb Makowski (35 lat), a uprowadzeni - Szloma Wajnstein (34 lata) i Sura Fajgenbaum (54 lata) ${ }^{37}$.

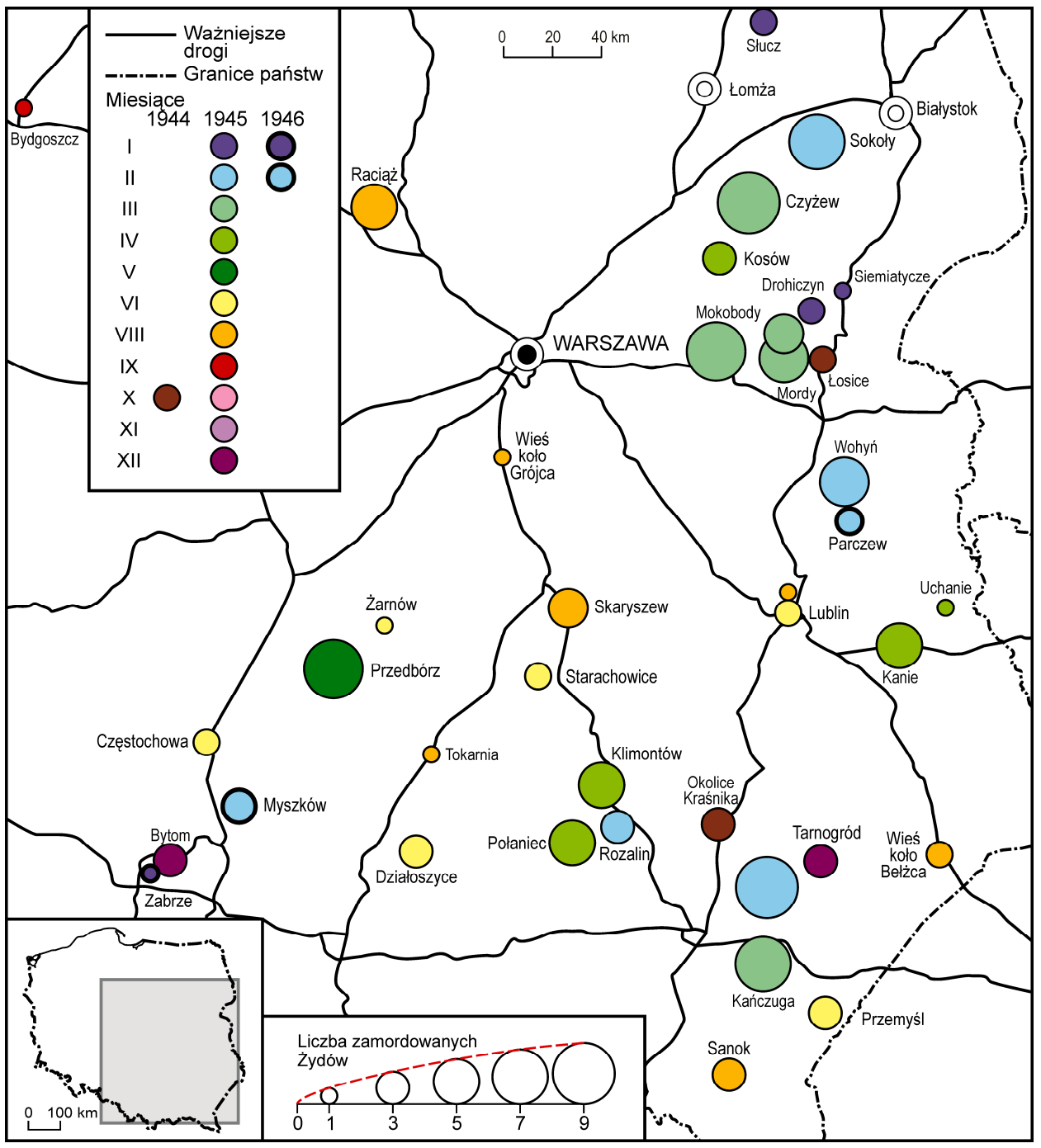

Ryc. 13. Wybrane miejsca zbrodniczych napaści Polaków na Żydów od końca października 1944 r. do początku lutego 1946 r.

Źródło: opracowanie własne

${ }^{37}$ AAN, MAP, DP, WN, sygn. 786, Odpisy niektórych mordów i rabunków dokonywanych na ludności polskiej narodowości żydowskiej. 
W tym samym miesiącu ofiarami morderstw stało się m.in. pięciu Żydów w Połańcu k. Staszowa i tyluż w Klimontowie (w powiecie sandomierskim). Mord połaniecki, którego dokonano 9 kwietnia, pochłonął życie dwóch dziesięcioletnich synów Chuny Bergera, Herszla Bergera, jego siostry i bratowej. Ranni zostali: wspomniany Chuna, jego siostrzenica i bratanek oraz Berek Berger. Z kolei w Przedborzu 27 maja 1945 r. w wyniku napaści antysemickiej śmierć poniosło osiem osób o $^{38}$.

W czerwcu, tj. w pierwszym miesiącu wolnym od działań wojennych, zamordowano dwie osoby w Częstochowie (1 czerwca), tyleż samo odpowiednio w Lublinie ( 9 czerwca) i Starachowicach (14 czerwca). Zabójstwa trzech osób pochodzenia żydowskiego (a zranienia i ciężkiego pobicia - co najmniej 50) dokonano w Działoszycach (w nocy z 16 na 17 czerwca). Kolejne trzy to bilans mordów, jakich polscy współobywatele dopuścili się w Przemyślu (18 czerwca). Tyleż samo ofiar (trzy) przyniosły akty terroru antyżydowskiego w Sanoku, do których doszło 12 sierpnia. Z kolei w dniu 25 tegoż miesiąca cztery osoby narodowości żydowskiej zamordowano w Skaryszewie. Jednym z najbardziej bestialskich aktów przemocy, które u powracających do rodzinnych miejscowości wywoływały nie tylko lęk, ale i zwątpienie w możliwość odbudowy życia w Polsce, było zamordowanie pięciu Żydów w Raciążu 13 sierpnia 1945 r. W ciągu dwóch dni (1617 grudnia) śmierć z rąk polskich obywateli (w tym sierżanta Wojska Polskiego) poniosły odpowiednio jedna i dwie osoby narodowości żydowskiej w Bytomiu ${ }^{39}$. W Tarnogrodzie 20 grudnia 1945 r. mord dosięgnął trzech Żydów, a wśród nich dziewięciomiesięczne dziecko. „Działo się to w Tarnogrodzie powiatu Biłgorajskiego" - jak zeznawał 16-letni Szloma Fajner. Dnia 20 grudnia 1945 r. Chaim Fainer (ojciec Szlomy, zamieszkały we Wrocławiu), udając się do Bilgoraja, swojego rodzinnego miasta, odwiedził po drodze rodzinę żydowską w Tarnogrodzie, u której chciał przenocować. W mieszkaniu, do którego dotarł, obecni byli wtedy Pesa Wachnachter (35 lat), jej 9-miesięczne dziecko oraz Symcha Sztatfeld, który - jak wynikało z zeznań Ojzera Wachnachtera, męża Pesy - opuścił je z powodu przybyłego w tym czasie i podejrzanie zachowującego się Rocha Botka. Wołanie „Gdzie tu są Żydzi?” zmusiło sąsiada Wachnachterów, Ostrowskiego, do wpuszczenia intruzów, którzy zabili wszystkich obecnych tam Żydów: Chaima Fainera, Pesę Wachnachter (35 lat) i jej dziecko. W wojewódzkiej Komendzie Bezpieczeństwa mąż Pesy Wachmachter i Sztatfeld jako sprawców tego czynu podali Botka

\section{${ }^{38}$ Ibidem.}

39 AAN, MAP, DP, WN, sygn. 786, 787; AAN, Polska Partia Robotnicza Komitet Centralny(dalej: PPR KC), Sekretariat, sygn. 295/ VII/ 149, k. 245-334; URM, Biuro Prezydialne 5/17. 
i Ostrowskiego. Po upływie pięciu tygodni od zbrodni nie dość, że nie rozpoczęto żadnego śledztwa, to jeszcze „do ostatniego Żyda tego miasteczka” zgłosił się urzędnik gminy ,z wezwaniem żeby podpisał protokół, że sprawa o powyższe zabójstwo została umorzona z powodu braku dowodów"40.

Wraz z upływającymi od zakończenia wojny miesiącami fala antyżydowskiej przemocy nie słabła. Jej kolejne nadejście zapowiadała repatriacja obywateli polskich z ZSRR. U jej progu, w lutym 1946 r., zbrodni dokonano m.in. na trzech Żydach w Myszkowie ${ }^{41}$ i tyluż samo w Parczewie ${ }^{42}$.

W dniu 5 lutego br. miasteczko Parczew zostało otoczone przez umundurowaną bandę napastników w sile 100 do 120 ludzi, uzbrojonych w broń palną. W ciągu 5 godzin banda bezkarnie szalała na terenie miasteczka. $Z$ rąk napastników padli bezbronni obywatele polscy, narodowości żydowskiej, Turbiner Mendel, 1. 31, Zysman Abram, 1. 43, Tempy Dawid, 1. 42, raniono Frajbergera Lejba. Prawie wszystkie mieszkania żydowskie zostały ograbione, dobytek złożony na furmanki i wywieziony; w szeregu wypadków, gdy mienie żydowskie nie przedstawiało dla napastników interesu, zostało ono zniszczone tak, że straciło wszelką wartość użytkową $^{43}$.

W wyniku tego tragicznego wydarzenia oraz braku właściwej reakcji służb odpowiedzialnych za bezpieczeństwo miejscowa społeczność żydowska (ok. 200 osób), ,zlikwidowawszy w pośpiechu swoje sprawy osobiste, opuściła miasteczko" $"$.

Ofiarami mordów padały także pojedyncze osoby, m.in. w Żarnowie (w nocy z 10 na 11 czerwca 1945 r.), Lublinie (17 sierpnia), w Tokarni k. Radomia (w sierp-

${ }^{40}$ AAN, MAP, DP, WN, sygn. 787, Protokół sporządzony przez urzędnika CKŻP N. Blumencwajga, 28 stycznia 1946 r., na podstawie zeznań Szlomy Fajnera.

41 AAN, MAP, DP, WN, sygn. 787, Memoriał Wojewódzkiego Komitetu Żydowskiego w Lublinie, z 23 marca 1946 r., w sprawie bezpieczeństwa życia i mienia żydostwa polskiego; AAN, MAP, DP, WN, sygn. 787, Komunikat WKŻ w Katowicach (dla CKŻP) w sprawie mordów Żydów w Gliwicach i Myszkowie, z 4 lutego 1946 r.

42 AAN, MAP, DP, WN, sygn. 786, Odpis protokołu sporządzonego przez WKŻ w Lublinie, 8 lutego 1946 r., w sprawie zajść w Parczewie. Żydów służących w ORMO, którzy zginęli w Parczewie z rąk oddziału WiN, A. Żbikowski (2006) umieszcza wśród ofiar przypadkowych. Przypuszczony na nich atak miał wynikać z przyczyn głównie ideowych (niezgody na siły nowego porządku) i rabunkowych.

43 AAN, MAP, DP, WN, sygn. 787, Memoriał Wojewódzkiego Komitetu Żydowskiego w Lublinie, z 23 marca 1946 r., w sprawie bezpieczeństwa życia i mienia żydostwa polskiego; AAN, MAP, DP, WN, sygn. 786, Odpis protokołu sporządzonego przez WKŻ w Lublinie, 8 lutego 1946 r., w sprawie zajść w Parczewie.

${ }^{44}$ AAN, MAP, DP, WN, sygn. 787, Memoriał Wojewódzkiego Komitetu Żydowskiego w Lublinie, z 23 marca 1946 r., w sprawie bezpieczeństwa życia i mienia żydostwa polskiego. 
niu), Bydgoszczy (we wrześniu), Zabrzu (19 stycznia 1946 r.) ${ }^{45}$. Do aktów terroru, wymierzonych w ocalałych, dochodziło również poza zwartymi skupiskami osadniczymi, często podczas tzw. akcji pociągowej, dokonywanej przez różne grupy zbrojnego podziemia antykomunistycznego. Między innymi 30 czerwca 1945 r. w pociągu przemieszczającym się między Łukowem a Międzyrzeczem zamordowano Jakuba Maglińskiego i Rywkę Starec, natomiast 22 sierpnia $4 \mathrm{~km}$ od Bełżca - siedziby niedawnego obozu zagłady - zastrzelono dwie osoby i tyleż zraniono ${ }^{46}$.

„Zdławienie faszyzmu niemieckiego dotąd nie przyniosło żydostwu polskiemu upragnionego spokoju" - donosił w memoriale poświęconym bezpieczeństwu Żydów Lubelszczyzny tamtejszy Wojewódzki Komitet Żydowski (dalej: WKŻ). W dokumencie tym czytamy także:

Żydzi, którzy wyszli z bunkrów, z lasów, Żydzi, którzy powrócili z obozów, z zesłania, $\mathrm{z}$ emigracji, $\mathrm{w}$ wielu wypadkach spotkali się $\mathrm{z}$ wrogą postawą ze strony części społeczeństwa polskiego. [...] nie czując się bezpieczni [...], dążą do nielegalnego przekroczenia granicy, tworząc po drugiej stronie, ku zdumieniu świata, liczne grupy uciekinierów z Polski, z Polski wyzwolonej od niemców ${ }^{47}$.

Przemocy doświadczali również Żydzi przybywający do Polski z ZSRR w ramach zorganizowanej, tzw. legalnej repatriacji, którzy posiadając do 17 września 1939 r. obywatelstwo polskie, zamieszkiwali na stałe ziemie przejęte przez Związek Radziecki (tzw. Kresy Wschodnie) oraz przebywali w centralnej i wschodniej części Związku Radzieckiego (od lutego do czerwca 1946 r. powroty objęły 120579 Żydów) (Zarys... 1947, s. 13, Grynberg 1986, s. 20$)^{48}$.

Choć problem stosunku społeczeństwa polskiego do żydowskich repatriantów wykracza poza zakres czasowy analizy, warto nadmienić, że przemoc, jakiej doznawali, przybierała rozmaite odcienie: od wyśmiewania, poprzez szykany i poni-

${ }^{45}$ AAN, MAP, DP, WN, sygn. 786, Odpisy niektórych mordów i rabunków dokonywanych na ludności polskiej narodowości żydowskiej; AAN, MAP, DP, WN, sygn. 787, Odpis sprawozdania, z 23 stycznia 1946 r., z zabójstwa osoby narodowości żydowskiej w Zabrzu, stanu śledztwa, zachowania się społeczeństwa polskiego, stanowiska władz miejskich i partyjnych oraz przebiegu pogrzebu; AAN, PPR KC, Sekretariat, sygn. 295/VII/149, k. 245-334.

${ }^{46}$ AAN, MAP, DP, WN, sygn. 786, Odpisy niektórych mordów i rabunków dokonywanych na ludności polskiej narodowości żydowskiej.

${ }^{47}$ AAN, MAP, DP, WN, sygn. 787, Memoriał Wojewódzkiego Komitetu Żydowskiego w Lublinie, z 23 marca 1946 r., w sprawie bezpieczeństwa życia i mienia żydostwa polskiego.

${ }^{48}$ AŻIH, CKŻP, Wydział Ewidencji i Statystyki (dalej: WEiS), sygn. 474; AAN, MAP, DP, WN, sygn. 788; AŻIH, CKŻP, WEiS, sygn. 502, 507. 
żanie, po mordy. Powrót do kraju następował w okresie spowitym atmosferą, którą $\mathrm{w}$ dokumentacji sporządzanej wówczas przez Centralny Komitet Żydów w Polsce (CKŻP) - największą organizację reprezentującą tę społeczność - określano mianem „pogromowej” (Skibińska 2011, s. 52). Między innymi 21 kwietnia 1946 r. pięciu Żydów zabito, jak wynika ze sprawozdań CKZP, na drodze między Nowym Targiem a Krościenkiem, a 30. dnia tego miesiąca siedmiu - w okolicach

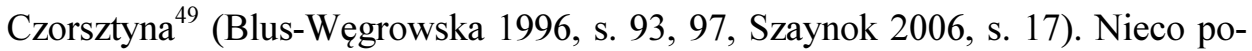
nad dwa miesiące później (23 czerwca) w Terespolu członkowie NSZ wyciągnęli i uprowadzili z pociągu członka Komisji Repatriacyjnej, na którym dokonali najprawdopodobniej egzekucji. Powtarzające się ataki wymusiły na Departamencie Politycznym MAP podjęcie decyzji o eskortowaniu pociągów z repatriantami od granicy radzieckiej do miejsca przeznaczenia ${ }^{50}$.

Podczas tzw. akcji pociągowej (kolejowej) z rąk zbrojnego podziemia antykomunistycznego (głównie NSZ) zginęło ok. 200 repatriantów żydowskich. Napadów dokonywano w celu wyłapania powracających Żydów. Akcja stanowiła rodzaj odwetu zbiorowego, bez rozstrzygania, czy ofiary były zaangażowane we wprowadzanie nowego systemu politycznego w kraju czy nie (Adelson 1993, s. 393, Żbikowski 2006, s. 251, Skibińska 2011, s. 52).

„Skrytobójcze mordy i zorganizowane napady uzbrojonych band”,51 skłaniały Żydów do emigracji: wewnętrznej - z małych miejscowości (z niewielką grupą ocalałych lub bez niej) do większych, a więc bardziej bezpiecznych i stwarzających perspektywę osiągnięcia względnej stabilizacji, oraz zewnętrznej - poza Polskę, trwającej nieprzerwanie od czasu wycofania się okupacyjnych wojsk niemieckich (Rykała 2007, s. 24, 26). W marcu 1946 r., a więc we wstępnej fazie legalnych powrotów ze Związku Radzieckiego, WKŻ z siedzibą w Lublinie sprawozdawał:

Nastroje paniki wśród Żydów wzrastają i obejmują coraz większe kręgi. Ich system wrażliwości nerwowej, nadwątlony w latach niemieckiej gehenny, w okresie krematoriów i komór gazowych, sprawia, że i ci Żydzi, którzy mieli w kraju pod-

49 AAN, MAP, DP, WN, sygn. 786; AAN, PPR KC, Sekretariat, sygn. 295/ VII/ 149, k. 245-334.

${ }^{50}$ AAN, PPR KC, Sekretariat, sygn. 295/ VII/ 149, Protokół oświadczenia złożonego 25 czerwca 1946 r. przez Chaima Orimlanda w Wojewódzkim Komitecie Żydowskim w Łodzi; AAN, MAP, DP, WN, sygn. 786, Komunikat dyrektora Departamentu Politycznego MAP dla Generalnego Pełnomocnika Rządu do Spraw Repatriacji, z 25 czerwca 1946 r., w sprawie napadów na pociągi z repatriantami.

${ }^{51}$ AAN, URM, Biuro Prezydialne 5/17, Dziesiąte sprawozdanie (za kwiecień 1945 r.) z działalności Referatu dla Spraw Pomocy Ludności Żydowskiej przy Ministerstwie Pracy i Opieki Społecznej. 
stawę bytu, opartą na zdrowych zasadach gospodarczych i społecznych, porzucają swój dom i warsztaty pracy, byle znaleźć się poza terenem objętym zarazą antysemityzmu ${ }^{52}$.

\section{Miejsca niepamięci, nie-miejsca pamięci - refleksja końcowa}

Odwołując się do szacunków historyków, etnologów, socjologów (zwłaszcza D. Engela, A. Skibińskiej, A. Żbikowskiego, A. Całej, J. Grossa), podczas dokonywania własnej analizy poświadczonych źródłowo kilkudziesięciu przypadków mordów Żydów, należy przyjąć, że w latach 1944-1947 w ten sposób straciło życie co najmniej 1000 osób narodowości żydowskiej, w tym kobiety i dzieci. Prawdopodobnie tylko w 1945 r. śmierć z rąk polskich dosięgła 353 ocalałych (Kopciowski 2007, s. 205, Skibińska 2007, s. 568, Żbikowski 2011, s. 91) ${ }^{53}$. Łączna liczba śmiertelnych zajść - w wielu przypadkach zabójstw o charakterze zbiorowym - oscylowała między 200 a 300 (Żbikowski 2011, s. 93, Skibińska 2011, s. 64-65, Cała 2014, s. 17, Grabski 2002, s. 73). Areną zdecydowanej większości wystąpień antyżydowskich były tereny wschodniej, południowo-wschodniej i centralnej Polski. Przerażenie ludności żydowskiej skalą morderstw potęgowała bezkarność sprawców.

Pod wpływem skrytobójczych mordów i zorganizowanych napadów - stanowiących ciągłość aktów przemocy antyżydowskiej w Polsce od co najmniej lat 30. XX w., wzmocnionych okupacyjnym systemem prawnym i zmasowaną antysemicką propagandą hitlerowską - dokonywała się w naszym kraju, jak stwierdziła A. Cała (2014, s. 27), czystka etniczna. Została ona ,zapoczątkowana deportacjami przeprowadzonymi przez hitlerowców, a zakończona ekspulsją Żydów z Polski w 1968 r." (Cała 2014, s. 27). Choć przesunięcie granicy czasowej dopełnienia czystki etnicznej na wiele lat po wojnie może budzić kontrowersje, zważywszy na odmienność położenia ludności żydowskiej w okresie trwania tego światowego konfliktu oraz ponad dwie dekady po jego zakończeniu, to nie ulega wątpliwości, iż pod wpływem brutalnej, państwowej nagonki antysemickiej - podchwyconej przez część społeczeństwa, a w znakomitej większości wobec niej obojętnego - do wyjazdu z kraju zmuszonych zostało co najmniej 12 tys. osób

52 AAN, MAP, DP, WN, sygn. 787, Memoriał Wojewódzkiego Komitetu Żydowskiego w Lublinie, z 23 marca 1946 r., w sprawie bezpieczeństwa życia i mienia żydostwa polskiego.

${ }^{53}$ Przykładowo na Lubelszczyźnie między latem 1944 r. a wrześniem 1946 r. w ok. 30 zajściach zamordowanych zostało, niekiedy podczas stoczonych walk, 118 Żydów (Kopciowski 2007, s. 205). 
pochodzenia żydowskiego, co doprowadziło do radykalnego zmniejszenia się (o blisko połowę) stanu liczebnego tej mniejszości w Polsce ${ }^{54}$.

Upamiętnienia $\mathrm{w}$ przestrzeni doczekały się jedynie nieliczne $\mathrm{z}$ tak wielu przypadków powojennej przemocy wobec Żydów. Do ustanowienia miejsca pamięci - będącego, zdaniem M. Delaperriére (2013, s. 58-59), historycznym, symbolicznym i etycznym punktem odniesienia w kształtowaniu się świadomości kulturowej $^{55}$ - dochodziło zazwyczaj w stosunku do tych aktów zbrodni, które pochłonęły największą liczbę ofiar, zdarzyły się w dużych miastach, zostały precyzyjnie zlokalizowane oraz doczekały się - w związku z takim właśnie bagażem cech - naukowych opracowań (by wspomnieć np. pogromy w Krakowie w sierpniu 1945 r. czy w Kielcach w lipcu następnego roku). Należy założyć, że te co najmniej 200 miejsc dokonania zbrodni na ocalałych - odwołanie się do wartości przybliżonej pokazuje, że na tym podstawowym poziomie rozpoznania nie łatwo o jednoznaczne rozstrzygnięcie - nigdy nie zostanie objętych jakimikolwiek formami upamiętnienia ${ }^{56}$. Topograficzne oznaczenie informacji o aktach terroru i ich ofiarach wydaje się niemożliwe z powodu trudności w identyfikacji umiejscowienia wielu takich zajść. Tereny, na których do nich doszło, uległy po wojnie znaczącym zmianom w zagospodarowaniu. W rezultacie nie tylko zmalała możliwość dokonania przestrzennej identyfikacji śladów miejsc zbrodniczego czynu, ale i wprowadzenia upamiętniających je założeń (wśród potencjalnych przeszkód należałoby wymienić: stan własności, rodzaj i formę użytkowania, a przede wszystkim pozostającą z tymi czynnikami w koincydencji wolę użytkowników). Poza

${ }^{54}$ Po zmniejszeniu się fali tzw. marcowej emigracji w 1971 r. w Polsce pozostało ok. 13,5 tys. Żydów (Archiwum Towarzystwa Społeczno-Kulturalnego Żydów w Polsce, materiały nieuporządkowane, Rykała 2007).

${ }^{55}$ Miejsce pamięci - określenie łączące miejsce i pamięć - jest wyrażane topograficznie i symbolicznie. Według M. Delaperriére (2013, s. 49) oznacza ono zarówno konkretny topograficzny punkt zaczepienia, jak i wszystkie materialne i niematerialne znaki i ślady przywołujące przeszłość w pamięci zbiorowej. W tym pierwszym znaczeniu miejsce pamięci obejmuje m.in.: pomniki, tablice pamiątkowe, zabytki, relikty, ruiny budowli, muzea, cmentarze. Inny sposób wyrażania tych miejsc (materialne i niematerialne znaki oraz ślady) ma wspomniany sens symboliczny (metaforyczny). Z powodu naznaczenia śmiercią lub cierpieniem pozostają także miejscami, w których się wspomina („miejscami wspominania").

${ }^{56}$ Upamiętnianiu przeciwstawiane jest zapominanie (będące składową pamięci, jako jej przeciwieństwo, a zarazem dopełnienie). Można w związku z tym wskazać na miejsca zapomnienia, będące topograficznym zakotwiczeniem tylko dla nielicznych, pojedynczych osób (które jako jedyne te punkty w krajobrazie wyróżniają, znają ich charakter, niekiedy o nich dyskutują). W odniesieniu do krajobrazu (miejskiego) T. Majewski (2011, s. 211) definiuje ten proces pamięciowy jako ,pustoszenie przestrzeni, pozbawianie jej znaczeń”. 
miastami miejsca, o których tu mowa, miały topograficzne zaczepienie w granicach wsi, obok terenów zurbanizowanych - także na łąkach i w lasach. Niekiedy wyodrębniają się z krajobrazu jakimiś antropogenicznymi konstrukcjami, na ogół jednak nic nie wyróżnia wspomnianych miejsc: interferują z zabudowaniami, przykryte są kępami traw, krzaków, przywalone pagórkami ${ }^{57}$. Choć jak zauważyła R. Sendyka (2013, s. 278), miejsca te „pozornie nie różnią się od otoczenia, coś niepokojącego jednak okrąża je i wyodrębnia".

Forma publicznej komemoracji zarezerwowana jest zazwyczaj dla postaci, wydarzeń i czynów mających szczególny, doniosły wymiar dla kształtowania się różnych sfer życia o takim właśnie statusie - publicznym. W układzie wzajemnych odniesień polsko-żydowskich w okresie tużpowojennym taką rangę zyskał pogrom kielecki - jako największy po Holokauście akt antysemickiej zbrodni, którego konsekwencją była emigracja Żydów z Polski na niespotykaną skalę, a w jej następstwie - radykalne zmniejszenie się ich skupienia. Wydarzenie to stało się symbolem nacechowanego uprzedzeniem, wykluczeniem, szykanowaniem, dyskryminowaniem, niechęcią, a nawet wrogością stosunku Polaków do Żydów. W takim znaczeniu Kielce - podobnie jak Jedwabne dla okresu drugiej wojny światowej - stały się pojęciem i znakiem wyrażającym nie wyłącznie tę konkretną miejscowość, ale umowną reprezentację kilkudziesięciu, kilkuset miejsc dokonania mordów na Żydach, popełnionych przez Polaków. Przy ewentualnym dążeniu do topograficznego oznaczenia aktów terroru, warto mieć na uwadze również wszystkie te osoby nieżydowskiego pochodzenia, których życie w podobnych lub innych okolicznościach zostało przerwane, choć nie z powodu przynależności etnicznej (religijnej), i które nie doczekały się jakiejś formy upamiętnienia. Istotą sprawy nie jest tu jednak kontekst rywalizacji o pierwszeństwo w cierpieniu między Polakami i Żydami (przecież ci drudzy, mimo świadomości swojego etnicznego pochodzenia, identyfikowali się często z polskością, a ich poczucie przynależności narodowej podlegało stopniowalności), ale wzbudzenie refleksji nad ocaleniem indywidualizmu wszystkich ofiar, niezależnie od ich proweniencji. W przypadku Żydów jednak idzie o społeczność, która w wyniku Zagłady oraz będącej jej następstwem emigracji stała się jedną z najmniej liczebnych mniejszości w Polsce, a w związku z tym została pozbawiona znaczącej siły w dochodzeniu do utrwalenia w przestrzeni lokalizacji naznaczonych bohaterskim czynem lub cierpieniem, czy też rewitalizacji ekspozycji już istniejących. Wobec inercji

${ }^{57}$ Roślinność tworzącą pokrycie miejsc naznaczonych heroizmem lub traumą można rozpatrywać w układzie dychotomicznym, jako niesłużącą (wrogą) pamięci o wydarzeniach (a już zwłaszcza o ofiarach) lub właściwą dla nich (nomen omen naturalną) - towarzyszącą ich przebiegowi i zaświadczającą o cierpieniu. 
właściwych organów państwowych podjęcie wysiłku nakierowanego na osiągnięcie tego celu - traktowanego często jako swego rodzaju zobowiązanie moralne - spoczęło więc w dużym stopniu na przedstawicielach społeczności żydowskiej, a także osobach z nią etnicznie niezwiązanych - ale zaangażowanych na wiele sposobów w pielęgnowanie dziedzictwa polskich Żydów - które żydowskich współobywateli postrzegają jako integralną część polskiej historii, wręcz składową polskiej tożsamości narodowej ${ }^{58}$.

58 Dbałość o przywracanie pamięci miejsc (lub większych fragmentów przestrzeni) naznaczonych heroicznymi lub traumatycznymi wydarzeniami polega również na przeciwdziałaniu zasłonięciu - czynionemu często w geście upamiętnienia - inną obecnością. Starania takie prowadzone są np. w odniesieniu do terenu dawnego getta warszawskiego, jako że podejmowane są próby pozbawienia tego miejsca jego znaczeń poprzez realizację planu budowy pomnika Sprawiedliwych wśród Narodów Świata, honorującego Polaków ratujących Żydów podczas drugiej wojny światowej, mającego stanąć tuż obok Muzeum Historii Żydów Polskich oraz pomnika Bohaterów Getta. Wśród obrońców nienaruszania pamięci (i jej znaków), ,wypalonej” przestrzeni gettowej - coraz silniej, dzięki pracy wielu instytucji naukowych i organizacji społecznych, utrwalanej zarówno w imaginacyjnej topografii, jak i w postaci znaków symbolizujących dramatyczne wydarzenia powstańcze - znaleźli się m.in. uczestnicy zrywu w zamkniętej dzielnicy, przedstawiciele polskich Żydów, badacze problematyki żydowskiej. Protestujący, oddając cześć i chwałę oraz wyrażając wdzięczność polskim Sprawiedliwym, popierali jak najbardziej ideę uhonorowania niosących ratunek pomnikiem, zwłaszcza że wielu z nich pozostało osobami anonimowymi, ponieważ z powodu swojego bezprzykładnego męstwa musieli się ukrywać przed polskimi sąsiadami. Przeciwnicy dekonstrukcji tej swoistej topografii pustki w krajobrazie kulturowym, powodowani szczególnym rodzajem zobowiązania wobec tysięcy ofiar - na tym skrawku ziemi żyjących, cierpiących, poddawanych bezprzykładnemu naruszeniu ich godności, wreszcie ginących - wystosowali apele i skierowali pisma do odpowiednich instytucji. W 2015 r. list otwarty do prezydentów Polski i Warszawy skierowali uczestnicy powstania w warszawskim getcie, Pnina Grynszpan Frymer i Simcha Rotem Ratajzer (ps. Kazik). Napisali w nim: „Nie możemy [...] zrozumieć, dlaczego ten pomnik miałby stanąć w miejscu, gdzie setki tysięcy ludzi zginęły samotnie, nie doczekawszy pomocy, w sąsiedztwie pomnika, który jest ich symbolicznym nagrobkiem, miejscem pamięci. [...] Prosimy o zachowanie dla nich tego skrawka byłego getta, o uszanowanie uczuć tych, którzy czują się strażnikami pamięci. [...] Warszawa jest wielka. Na pamięć należną Sprawiedliwym na pewno można znaleźć w Warszawie wiele godnych miejsc. Bardzo o to prosimy" (Pomnikowi...). W innych listach otwartych, inicjujących dyskusję wokół pomnika podkreślono, że „Pomnik wdzięczności dla ludzi ratujących Żydów ma stanąć wśród prochów tych, którym nikt nie pomógł i nie chciał pomóc. Zaginie w tym los Żydów, którzy umierali w krańcowej samotności” (Janicka, Keff, Datner 2014, s. 39). „Ten symbol [pomnik ku czci Sprawiedliwych - przyp. A.R.] odbiera głos tysiącom istniejących żydowskich świadectw i liczniejszym jeszcze tym, które nie zostały zapisane, ponieważ ich bohaterowie nie przeżyli, i które nie są opowieścią o Sprawiedliwych, lecz o szantażach, donosach, wykorzystaniu, wyrzuceniu, wytropieniu, ograbieniu i śmierci. [...] Nadal nie dość powtarzać, że [Sprawiedliwi - przyp. A.R.] NIE (podkreślenie - oryg.) działali [...] 
Dążąc do identyfikacji przesiąkniętych tragedią punktów czasoprzestrzeni historycznej, za prymarne można uznać uczynienie ich składowymi świadomości zbiorowej. Ważne jest więc, aby miejsca rozgrywania się przywołanych wydarzeń stały się lokum skupiającym dramatyczne żydowskie historie, nabrały właściwości polegających na przekształcaniu się w nośniki pamięci o ofiarach, były punktami zaczepienia dla lokalnej - i nie tylko - tożsamości (źródłem uświadamiania, że stało się to w tej miejscowości, w jej pobliżu, tutaj, choć trudno rozpoznać, gdzie dokładnie). Tworzeniu nowej relacji czasoprzestrzennej sprzyja bowiem dynamika tych miejsc, które „są”, a zarazem - wskutek różnych oddziaływań - „stają się”. Chęć doświadczenia empatii („współodczuwania”) ${ }^{59}$, wynikająca m.in z uświadomienia sobie uczestnictwa we wspólnym dla danego obszaru dziedzictwie kulturowym, może znacząco sprzyjać ustanowieniu takiego lokum. Choć doprowadzi to do naruszenia utrwalonego przez cały okres powojenny porządku kulturowej percepcji danego wycinka przestrzeni.

Teraz punkty znaczone otchłanią bólu są na ogół miejscami niepamięci, a więc nierozpoznawanymi przez lokalną społeczność. Jeśli tę niepamięć udaje się przełamać - co oznacza, że ich status podlega zmianie (,stają się") - to raczej z zewnątrz, w wyniku dyskursu toczonego poza lokalną społecznością (np. przez uczestników i świadków wydarzeń, badaczy, aktywistów odkrywających historię małych ojczyzn) i na podstawie kryteriów ustalanych bez jej wpływu.

Miejsca masowych mordów na Żydach występują też jako miejsca niesłużące okolicznej ludności do zakorzenienia w nich swojej pamięci, gdyż zostały „,porzucone", nieoznaczone. Inaczej jednak niż miejsca niepamięci, są obecne w życiu lokalnych społeczności, ale zdaniem R. Sendyki (2013, s. 280-281, 283), omijane, nienazywane - jako miejsca tabu. „Pamięć o nich nie ujawnia się w porządku kultury materialnej (nie stawia się na nich tablic)" (Sendyka 2013, s. 280). Według badaczki ,[...] społeczność topograficznie przypisana danej lokalizacji nie ma potrzeby lokować" w tych miejscach swojej pamięci, chce o nich zapomnieć, woli o nich nie pamiętać (Sendyka 2013, s. 281). R. Sendyka zauważa również, że „[...] jakością charakteryzującą [...] jest ich niewidzialność, przezroczystość [...]” (Sendyka 2013, s. 283). Dla otaczającej je wspólnoty są na tyle niewygodne, że ich upamiętnienie traktuje ona jako większe zagrożenie dla zbiorowej tożsamości niż jego zaniechanie (Sendyka 2013, s. 281). Stanowią one więc - powołując się

w imieniu narodu polskiego. [...] działali WBREW (podkreślenie - oryg.), a nie za przyzwoleniem większości, stając się we własnym kraju mniejszością, z wszystkim, co to oznacza" (Keff, Datner, Janicka 2014).

${ }^{59}$ Zwrotu ,pragnienie doświadczenia empatii” użyła w swojej książce A. Łebkowska (2018, s. 18). 
na określenie C. Lanzmanna, reżysera filmu Shoah (za: Sendyka 2013, s. 279) - „nie-miejsca pamięci”, ${ }^{60}$.

Poddając się hermeneutyce (nie-)miejsc (nie)pamięci można dojść do wniosku, że jednym z nomen omen miejsc przywracania pamięci pozostaje tekst. Uobecnia przeszłość dzięki przekazywaniu ułamków czyjejś pamięci (często okaleczonej), relacji ocalałych i świadków czy odkrywaniu zawartości źródeł archiwalnych, poświęconych dramatycznym sytuacjom. Daje sposobność „nasycenia" tych (nie-)miejsc refleksją i wyobraźnią czytelnika, dzięki którym można zidentyfikować - nie tylko topograficznie - ślady traumatycznych wydarzeń przysłonięte warstwami niewiedzy, niepamięci, obojętności, ignorancji czy przemilczania $^{61}$. Wydrążonym z części „,wnętrza"62 i pozbawionym treści loci-o mniej lub bardziej dających się określić zasięgach - przywróćmy pamięć o przerwanym w nich życiu ocalałych z Zagłady: Herszla Bergera, jego siostry, bratowej, synów Chuny Bergera, Chaima Fainera, Dawida Grungrasa, Gity Jabłkowskiej, Jakuba Maglińskiego, Icka Majdenberga, Majzelsa, Hersza Siedleckiego, Rywki Starec, Dawida Tempego, Mendla Turbinera, Pesy Wachnachter i jej dziecka, Blumy Wajn, Zeliga Weisberga, Abrama Zysmana...

\section{Literatura}

Adelson J., 1993, W Polsce zwanej Ludowa, [w:] Tomaszewski J. (red.), Najnowsze dzieje Żydów w Polsce. W zarysie (do 1950) roku, Warszawa, s. 387-477.

Bikont A., 2004, My z Jedwabnego, Warszawa.

Blus-Węgrowska D., 1996, Atmosfera pogromowa, „Karta”, 18, s. 87-106.

Cała A., 2000, Ksztaltowanie się polskiej $i$ żydowskiej wizji martyrologicznej po II wojnie światowej, „Przegląd Socjologiczny”, 2, s. 167-180.

Cała A., 2014, Ochrona bezpieczeństwa fizycznego Żydów w Polsce powojennej. Komisje specjalne przy Centralnym Komitecie Żydów w Polsce, Warszawa.

${ }^{60}$ Shoah, reżyseria: Claude Lanzmann, rok produkcji: 1985.

${ }^{61}$ Jest to niemal wkroczenie na obszar postpamięci, którą - w kontekście interpretacji miejsc pamięci - ujmuje się jako afirmację powstałą dzięki sile działania empatii zdolnej nasycić puste miejsca wyobraźnią oglądającego (Delaperriére 2013).

${ }^{6}$ Określenie zaczerpnięto z pracy J. Leociaka (2007, s. 494), który używając go w odniesieniu do terenu byłego warszawskiego getta, pisał: „Miejsce ocalało, ale zostało niejako wydrążone, pozbawione «treści», «wnętrza». Getto, które tutaj było, uległo zagładzie, ale owo «tutaj» pozostało, tylko jest zasłonięte inną obecnością. Zostały ramy, które mieszczą w sobie już inną rzeczywistość, pozostał punkt topograficzny, kartograficzna abstrakcja". 
Cała A., Datner-Śpiewak H., 1997, Dzieje Żydów w Polsce 1944-1968. Teksty źródłowe, Warszawa.

Czubryt-Borkowski Cz. (red.), 1988, Przewodnik po upamiętnionych miejscach walk i męczeństwa; lata wojny 1939-1945, Warszawa.

Datner H., Melchior M., 1997, Żydzi we wspólczesnej Polsce - nieobecność i powroty, [w:] Kurcz Z. (red.), Mniejszości narodowe w Polsce, Wrocław, s. 63-81.

Datner S., 1966, Eksterminacja ludności żydowskiej w Okręgu Białostockim, „Biuletyn Żydowskiego Instytutu Historycznego", 60, s. 3-50.

Delaperriére M., 2013, Miejsca pamięci czy pamięć miejsc? Kilka refleksji na temat uobecniania przeszłości w literaturze współczesnej, „Ruch Literacki”, LIV, 1 (316), s. 49-61.

Dmitrów E., 2002, Oddziały operacyjne niemieckiej Policji Bezpieczeństwa i Stużby Bezpieczeństwa a początek zagłady Żydów w Lomżyńskiem i na Białostocczyźnie latem 1941 roku, [w:] Machcewicz P., Persak K. (red.), Wokót Jedwabnego, t. 1: Studia, Warszawa, s. 273-352.

Engel D., 1998, Patterns of anti-Jewish violence in Poland 1944-1946, „Yad Vashem Studies", 26, s. 43-85.

Engelking B., 2011, Jest taki piękny słoneczny dzień. Losy Żydów szukających ratunku na wsi polskiej 1942-1945, Warszawa.

Engelking B., Grabowski J. (red.), 2011, Zarys krajobrazu. Wieś polska wobec zagłady Żydów 1942-1945, Warszawa.

Engelking B., Grabowski J. (red.), 2018, Dalej jest noc. Losy Żydów w wybranych powiatach okupowanej Polski, t. I i II, Warszawa.

Grabowski J., 2008, Ratowanie Żydów za pieniądze: przemyst pomocy, „Zagłada Żydów. Studia i Materiały", 4, s. 81-109.

Grabowski J., 2011, Judenjagd. Polowanie na Żydów 1942-1945. Studium dziejów pewnego powiatu, Warszawa.

Grabski A., 2002, Żydowski ruch kombatancki w Polsce 1944-1949, Warszawa.

Grabski A., 2004, Działalność komunistyczna wśród Żydów w Polsce (1944-1949), Warszawa.

Grabski A (red.), 2007, Żydzi a lewica. Zbiór studiów historycznych, Warszawa.

Grabski A., Rykała A., 2010, Żydzi w Polsce 1944-2010, [w:] Sienkiewicz W. (red.), Atlas historii Żydów polskich, http://www.dobraksiazka.pl/autor,Jacek-Wijaczka.htmlhttp:// www.dobraksiazka.pl/autor,Marcin-Wodzinski.htmlhttp://www.dobraksiazka.pl/autor, Hanna-Zaremska.htmlWarszawa.

Gross J.T., 2000, Sąsiedzi. Historia zagłady żydowskiego miasteczka, Sejny.

Gross J.T., 2002, Antoniemu Sulkowi w odpowiedzi, „Więź”, 4, s. 82-89.

Gross J.T., 2003, Wokót „, Sąsiadów”: polemiki i wyjaśnienia, Sejny.

Gross J.T., 2008, Strach. Antysemityzm w Polsce tuż po wojnie. Historia moralnej zapaści, Kraków. 
Grynberg M., 1986, Żydowska spółdzielczość pracy w Polsce w latach 1945-1949, Warszawa.

Hurwic-Nowakowska I., 1996, Żydzi polscy (1947-1950). Analiza więzi spolecznej ludności żydowskiej, Warszawa.

IPN wyrzuca naukowców. Polaków można przedstawiać tylko $w$ dobrym świetle, wywiad Aliny Pospischil z Adamem Puławskim, 2018, „Duży Format” - dodatek do „Gazety Wyborczej", 8 X, s. 21-23.

Jabłoński Z., 1998, Ochrona dziedzictwa historycznego w krajobrazie a działalność samorząów terytorialnych, [w:] Jabłoński Z., Tomaszewski W. (red.), Ochrona wartości przyrodniczych i kulturowych - metodyka opracowań studialnych, seria: Przegląd Regionalny, 3, 1, Toruń, s. 33-42.

Janicka E., Keff B., Datner E., 2014, Polska panika moralna. Czy upamiętnić Sprawiedliwych koło Muzeum Historii Żydów Polskich, „Gazeta Wyborcza”, 31 V-1 VI, s. 39.

Kaczyński A., 2000a, Całopalenie. W Jedwabnem zagłady Żydów Niemcy dokonali polskimi rękami, „Rzeczpospolita”, 5 V, s. 1, 3.

Kaczyński A., 2000b, Oczyszczenie pamięci, „Rzeczpospolita”, 19 V, s. 6.

Kainer A., 1983, Żydzi a komunizm, „Krytyka. Kwartalnik Polityczny”, 15, s. 214-247.

Kaleta E., 2018, Mój rodzinny żydowski dom, „Duży Format” - dodatek do „Gazety Wyborczej”, 19 XI, s. 18-19.

Kendziorek P., 2016, Program i praktyka produktywizacji Żydów polskich $w$ działalności CKŻP, Warszawa.

Kersten K., 1992, Polacy - Żydzi-komunizm. Anatomia pótprawd 1929-1968, Warszawa.

Kersten K., 1993, Między wyzwoleniem a zniewoleniem. Polska 1944-1956, Londyn.

Kopciowski A., 2007, Zajścia antyżydowskie na Lubelszczyźnie w pierwszych latach po drugiej wojnie światowej, „Zagłada Żydów. Studia i Materiały”, 3, s. 178-207.

Kuraś B., Zbrodnia na Żydach w Krościenku. «Mały jęczy, trzeba poprawić», „Gazeta Wyborcza", 28-29 V, s 32-33.

Leociak J., 2007, Warszawa: „Miejsce-po-getcie” jako palimpsest, [w:] Madurowicz M. (red.), Percepcja współczesnej przestrzeni miejskiej. Praca zbiorowa, Warszawa, s. 493-495.

Libionka D., 2006, Losy Chaima Hirszmana jako przyczynek do refleksji nad pamięcia o Zagładzie i powojennymi stosunkami polsko-żydowskimi, [w:] Eisler J., Szarota T. (red.), Polska 1944/45-1989. Studia i materiaty, t. 7, Warszawa, s. 5-23.

Łebkowska A., 2008, Empatia. O literackich narracjach przetomu XX i XXI wieku, Kraków.

Machcewicz P., Persak K. (red.), 2002, Wokót Jedwabnego, t. 1: Studia, t. 2: Dokumenty, Warszawa.

Majewski T., 2011, Ulice bez pamięci, [w:] Majewski T., Zeidler-Janiszewska A. (red.), Pamięć Shoah. Kulturowe reprezentacje i praktyki upamiętniania, Łódź, s. 209-211.

Milewski J.J., 2002, Zagłada Żydów w Wąsoszu w świetle akt sprawy karnej Mariana Rydzewskiego, „Biuletyn Historii Pogranicza”, 3, s. 87-112. 
Monkiewicz W., 1989, Zagłada skupisk żydowskich $w$ regionie białostockim $w$ latach 1939, 1941-1944, „Studia Podlaskie”, 2, s. 336-354.

Moroz A., Konflikt pamięci na pograniczu polsko-białoruskim na przykładzie działalności Romualda Rajsa ps. „Bury”, „Studia z Geografii Politycznej i Historycznej”, 5, s. 61-91.

Myga-Piątek U., 2012, Krajobrazy kulturowe. Aspekty ewolucyjne i typologiczne, Katowice.

Nalewajko-Kulikov J., 2009, Obywatel Jidyszlandu. Rzecz o żydowskich komunistach w Polsce, Warszawa.

Nora P., 1984, Les Lieux de mémorie, sous la direction de Pierre Nora, t. 1, Paris.

Orłowska E., 2005, Kulturowy aspekt badań geograficznych, [w:] Myga-Piątek U. (red.), Krajobraz kulturowy. Aspekty teoretyczne i metodologiczne, seria: Prace Komisji Krajobrazu Kulturowego PTG, 4, s. 55-64.

Paczkowski A., 2001, Żydzi w UB: próba weryfikacji stereotypu, [w:] Szarota T. (red.), Komunizm: ideologia - system - ludzie, Warszawa.

Persak K., 2016, Wydmuszka. Lektura krytyczna „Miast śmierci” Mirosława Tryczyka, „Zagłada Żydów. Studia i Materiały”, 12, s. 357-374.

Pisarski M., 1997, Emigracja Żydów z Polski w latach 1945-1951, [w:] Grabski A., Pisarski M., Stankowski A. (red.), Studia z dziejów i kultury Żydów w Polsce po 1945 r., Warszawa, s. 13-81.

Plit J., 2016, Krajobrazy kulturowe Polski i ich przemiany, seria: Prace Geograficzne, 253, Warszawa.

Rykała A., 2007, Przemiany sytuacji społeczno-politycznej mniejszości żydowskiej w Polsce po drugiej wojnie światowej, Łódź.

Rykała A., 2011, Mniejszości religijne w Polsce - geneza, struktury przestrzenne, tto etniczne, Łódź.

Rykała A., Wosiak A., 2019, Geograficzno-historyczne (polityczne) uwarunkowania genezy i przebiegu wybranych pogromów Żydów na ziemiach polskich od XIX w. do 1946 r. (w druku).

Schama S., 1996, Landscape and Memory, New York.

Sendyka R., 2013, Pryzma - zrozumieć nie-miejsce pamięci, [w:] Czaja D. (red.), Inne przestrzenie, inne miejsca. Mapy i terytoria, Wołowiec, s. 278-299.

Skibińska A., 2007, Powroty ocalatych, [w:] Engelking B., Leociak J., Libionka D. (red.), Prowincja noc. Życie i zaglada Żydów $w$ dystrykcie warszawskim, Warszawa.

Skibińska A., 2011, Powroty ocalalych i stosunek do nich spoleczeństwa polskiego, [w:] Tych F., Adamczyk-Garbowska M. (red.), Następstwa zagłady Żydów. Polska 19442010. Praca zbiorowa, Lublin.

Strzembosz T., 2001, Przemilczana kolaboracja, „Rzeczpospolita”, 27 I, s. 6-7.

Sułek A., 2001, „Sasiedzi” - zwykła recenzja, „Więź”, 12, s. 72-99.

Szaynok B., 2006, Polacy i Żydzi. Lipiec 1944-lipiec 1946, [w:] Kamiński Ł., Żaryn J. (red.), Wokót pogromu kieleckiego, Warszawa, s. 9-24. 
Śpiewak P., 2012, Żydokomuna. Interpretacje historyczne, Warszawa.

Tokarska-Bakir J., 2012, Okrzyki pogromowe. Szkice z antropologii historycznej Polski lat 1939-1946, Wołowiec.

Tokarska-Bakir J., 2018a, Pod klatwa. Spoleczny portret pogromu kieleckiego, t. 1 i 2: Dokumenty, Warszawa.

Tokarska-Bakir J., 2018b, Tryby maszyny pogromu, „Ale Historia”, 19 II, s. 4-7.

Tryczyk M., 2015, Miasta śmierci. Sąsiedzkie pogromy Żydów, Warszawa.

Tuwim J., 1993, My, Żydzi polscy..., Warszawa.

Urynowicz M., 2002, Ludność żydowska w Jedwabnem. Zmiany demograficzne od końca XIX wieku do 1941 roku na tle regionu tomżyńskiego, [w:] Machcewicz P., Persak K. (red.), Wokót Jedwabnego, t. 1: Studia, Warszawa, s. 83-104.

Wójcik J., 2016. Oddziat. Między AK i UB - historia żolnierzy Łazika, Warszawa.

Wroniszewscy D. i A., 1988, ...aby żyć, „Kontakty”, 10 VII, s. 1, 8-9.

Zarys dziatalności Centralnego Komitetu Żydów w Polsce za okres od 1 stycznia do 30 czerwca 1946 roku, 1947, Warszawa.

Zgliczyński S., 2013, Jak Polacy Niemcom Żydów mordować pomagali, Warszawa.

Żbikowski A., 1992, Lokalne pogromy Żydów w czerwcu i lipcu 1941 roku na wschodnich rubieżach II Rzeczypospolitej, „Biuletyn Żydowskiego Instytutu Historycznego”, 2/3, s. $3-18$.

Żbikowski A., 2002, Pogromy i mordy ludności żydowskiej w Łomżyńskiem i na Bialostocczyźnie latem 1941 roku w świetle relacji ocalalych Żydów i dokumentów sądowych, [w:] Machcewicz P., Persak K. (red.), Wokót Jedwabnego, t. 1: Studia, Warszawa, s. $159-271$.

Żbikowski A., 2006, U genezy Jedwabnego. Żydzi na Kresach Pólnocno-Wschodnich II Rzeczypospolitej, wrzesień 1939-lipiec 1941, Warszawa.

Żbikowski A., 2011, Morderstwa popetniane na Żydach w pierwszych latach po wojnie, [w:] Tych F., Adamczyk-Garbowska M. (red.), Następstwa zagłady Żydów. Polska 1944-2010. Praca zbiorowa, Lublin, s. 71-93.

Żbikowski A., 2018, Żydowski Instytut Historyczny. 70 lat badań nad dziejami polskich Żydów. Pisane z perspektywy historyka Zagłady, Warszawa.

\section{Źródla}

Archiwum Akt Nowych (dalej: AAN), Ministerstwo Administracji Publicznej (dalej: MAP), Departament Polityczny (dalej: DP), Wydział Narodowościowy (dalej: WN), sygn. 786.

AAN, MAP, DP, WN, sygn. 786, Komunikat dyrektora Departamentu Politycznego MAP dla Generalnego Pełnomocnika Rządu do Spraw Repatriacji, z 25 czerwca 1946 r., w sprawie napadów na pociągi z repatriantami. 
AAN, MAP, DP, WN, sygn. 786, Odpis protokołu sporządzonego 8 lutego 1946 r. przez WKŻ w Lublinie.

AAN, MAP, DP, WN, sygn. 786, Odpis protokołu sporządzonego przez WKŻ w Lublinie, 8 lutego 1946 r., w sprawie zajść w Parczewie.

AAN, MAP, DP, WN, sygn. 786, Odpisy niektórych mordów i rabunków dokonywanych na ludności polskiej narodowości żydowskiej.

AAN, MAP, DP, WN, sygn. 786, Pismo Departamentu Politycznego MAP do siedmiu wojewodów, z 21 III 1945 r.

AAN, MAP, DP, WN, sygn. 786, Pismo naczelnika Wydziału Społeczno-Politycznego MAP do Ministerstwa Bezpieczeństwa Publicznego, z 29 września 1945 r., w sprawie mordów i rabunków dokonywanych na obywatelach polskich narodowości żydowskiej.

AAN, MAP, DP, WN, sygn. 787.

AAN, MAP, DP, WN, sygn. 787, Komunikat WKŻ w Katowicach (dla CKŻP) w sprawie mordów Żydów w Gliwicach i Myszkowie, z 4 lutego 1946 r.

AAN, MAP, DP, WN, sygn. 787, Memoriał Wojewódzkiego Komitetu Żydowskiego w Lublinie, z 23 marca 1946 r., w sprawie bezpieczeństwa życia i mienia żydostwa polskiego.

AAN, MAP, DP, WN, sygn. 787, Odpis pisma dr. Horowitza, przewodniczącego, i dr. Reichmana, sekretarza generalnego Wojewódzkiego Komitetu Żydowskiego (dalej: WKŻ) w Krakowie, skierowanego do Centralnego Komitetu Żydów w Polsce (CKŻP), 4 maja 1946 r., w sprawie mordu Żydów pod Krościenkiem.

AAN, MAP, DP, WN, sygn. 787, Odpis pisma Powiatowego Komitetu Żydowskiego w Tarnowie do CKŻP w sprawie działalności Komisji Kwaterunkowo-Budowlanej i wojska, z dn. 13 listopada 1945 r.

AAN, MAP, DP, WN, sygn. 787, Odpis pisma WKŻ w Katowicach skierowanego 18 grudnia 1945 r. do Wojewódzkiego Urzędu Bezpieczeństwa publicznego w sprawie aktów antysemityzmu w województwie śląsko-dąbrowskim.

AAN, MAP, DP, WN, sygn. 787, Odpis sprawozdania, z 23 stycznia 1946 r., z zabójstwa osoby narodowości żydowskiej w Zabrzu, stanu śledztwa, zachowania się społeczeństwa polskiego, stanowiska władz miejskich i partyjnych oraz przebiegu pogrzebu.

AAN, MAP, DP, WN, sygn. 787, Pismo dyrektora Departamentu Politycznego MAP do Urzędu Wojewódzkiego w Kielcach, z 25 czerwca 1945 r.

AAN, MAP, DP, WN, sygn. 787, Protokół sporządzony przez urzędnika CKŻP, N. Blumencwajga, 28 stycznia 1946 r., na podstawie zeznań Szlomy Fajnera.

AAN, MAP, DP, WN, sygn. 787, Sprawozdanie Wydziału Narodowościowego Departamentu Politycznego MAP za okres od 1 października 1945 do 1 stycznia 1946 r.

AAN, MAP, DP, WN, sygn. 788.

AAN, Polska Partia Robotnicza Komitet Centralny, Sekretariat, sygn. 295/VII/ 149, k. 245334. 
AAN, PPR KC, Sekretariat, sygn. 295/ VII/ 149, Protokół oświadczenia złożonego 25 czerwca 1946 r. przez Chaima Orimlanda w Wojewódzkim Komitecie Żydowskim w Łodzi.

AAN, Urząd Rady Ministrów (URM), Biuro Prezydialne 5/17.

AAN, URM, Biuro Prezydialne 5/17, Dziesiąte sprawozdanie (za kwiecień 1945 r.) z działalności Referatu dla Spraw Pomocy Ludności Żydowskiej przy Ministerstwie Pracy i Opieki Społecznej.

AAN, URM, Biuro Prezydialne 5/17, Dwunaste sprawozdanie (za czerwiec 1945 r.) z działalności Referatu dla Spraw Pomocy Ludności Żydowskiej przy Ministerstwie Pracy i Opieki Społecznej).

AAN, URM, Biuro Prezydialne 5/17, Ósme sprawozdanie (za luty 1945 r.) Referatu dla Spraw Pomocy Ludności Żydowskiej dla Premiera Rządu Tymczasowego Rzeczpospolitej Polskiej, Edwarda Osóbki Morawskiego.

AAN, URM, Biuro Prezydialne 5/17, Ósme sprawozdanie (za luty 1945 r.) Referatu dla Spraw Pomocy Ludności Żydowskiej dla Premiera Rządu Tymczasowego Rzeczpospolitej Polskiej, Edwarda Osóbki Morawskiego.

AAN, URM, Biuro Prezydialne 5/17, Dziesiąte sprawozdanie (za kwiecień 1945 r.) z działalności Referatu dla Spraw Pomocy Ludności Żydowskiej przy Ministerstwie Pracy i Opieki Społecznej.

Archiwum Towarzystwa Społeczno-Kulturalnego Żydów w Polsce, materiały nieuporządkowane.

Archiwum Żydowskiego Instytutu Historycznego (dalej: AŻIH), Centralny Komitet Żydów w Polsce (dalej: CKŻP), Centralna Komisja Specjalna, sygn. 303/XVIII/20, Wykaz mordów dokonywanych na ludności żydowskiej.

AŻIH, CKŻP, Wydział Ewidencji i Statystyki (dalej: WEiS), sygn. 474.

AŻIH, CKŻP, WEiS, sygn. 502.

AŻIH, CKŻP, WEiS, sygn. 507.

AŻIH, CKŻP, Wydział Organizacyjny (dalej: WO), sygn. 15.

AŻIH, CKŻP, WO, sygn. 34.

\section{Źródła internetowe}

Aleksiun N., 2016, Zmarnowana szansa. O „Miastach śmierci” Mirosława Tryczyka, „Kultura Liberalna”, 3 (367): https://kulturaliberalna.pl/2016/01/19/zmarnowanaszansa-o-miastach-smierci-miroslawa-traczyka/ (15.12.2018).

https://sztetl.org.pl (15.10.2018).

Keff B., Datner H., Janicka E., 2014, Nie budujmy pomnika Sprawiedliwych obok Muzeum Historii Żydów Polskich, „Krytyka Polityczna”, 29 IV: https://krytykapolityczna.pl/kraj /nie-budujmy-pomnika-sprawiedliwych-obok-muzeum-historii-Zydow-polskich/ (15.12.2018). 
Pomnikowi Sprawiedliwych przy muzeum Polin? Bojownicy z getta sa przeciw: http:// warszawa.wyborcza.pl/warszawa/1,34862,17288913,Pomnikowi_Sprawiedliwych_prz y_muzeum_Polin_Bojownicy.html (15.12.2018).

W Warszawie odstonięto pierwsza dwujęzyczna „Tablicę Pamięci”: www.tvp.info; (26.10.2018).

\title{
On the "topography of emptiness" in the cultural landscape Places of non-remembrance, non-places of remembrance in the context of victims and circumstances of murders committed on Jews in Poland in the first months after the Second World War
}

\begin{abstract}
Summary
Writing about the annihilation of the unprecedented concentration of Jews in Poland, spurred by the unparalleled brutality of German perpetrators, we should also add that in the shadow of the Holocaust, and often hand-in-hand with its main architects, numerous members of Polish society also committed acts of aggression and terror. The most terrifying scale of acts of collective violence against the Jewish population broke out mainly in those areas captured by the Germans (Podlasie, especially its part between Grajew and Łomża, and eastern Galicia), which until mid-1941 were occupied by the Soviet Union. A wave of anti-Jewish terror has arrived in Radziłów on July 7. In the three-day pogrom - preceded by the campaign of destroying Torah scrolls and humiliating Jews (including shaving them) initiated by the Germans on July 25, 1941 local Poles, using the approval from German gendarmes, gathered most of their Jewish neighbours to a barn and burned them there, while the others were caught and killed in different ways. The number of murdered Jews is estimated at 600 . This former city did not, however, become a place of remembrance of the execution committed by Polish Christians on their Jewish neighbours. The monument commemorating their martyrdom still bears an inscription: "In August of 1941, the fascists murdered 800 people of Jewish nationality, they burnt 500 of these people in the barn. Honour their memory".

The approaching end of the Second World War and the inevitable defeat of Hitler's Germany did not mean the end of the drama of Jews in the Polish lands. In areas abandoned by German occupation forces, many survivors, often homeless, lonely and frightened, struggling with trauma and pain after the loss of their relatives, experienced further violence. Those guilty of crimes were usually not identified, and even if their identity was established, the acts they had committed did not prevent them in contemporary Poland from being granted the honour of being in the pantheon of the heroes of history written by the national majority (e.g. Józef Kuraś, pseudonym Ogień, responsible for the murders in Podhale).

In the opinion of many researchers (among others, A. Całej, H. Datner, D. Engel, A. Skibińska, A. Żbikowski), the war did not contribute in the slightest to softening or discrediting the prejudice of Poles towards Jews. Anti-Jewish stereotypes turned out to be permanent. It did not cause any compassion for the victims of the Holocaust, nor solidarity with them within the society at large. As Irena Hurwic-Nowakowska argued,
\end{abstract}


some part of it considered "the extermination of Jews" as "quite normal" conduct, a continuation of the "values and concepts" "implanted" during the occupation.

In turn, the places of many traumatic events, marked by the suffering and death of the Holocaust survivors, have not become points that would spark remembrance in local or supralocal communities. They have arranged themselves, "spread out" into another postwar layer of "burial", without a "definite place" to lay flowers, meditate or stop. There have been only few commemorations in space of so many cases of post-war violence against Jews. The establishment of a place of remembrance usually happened in relations to those crimes that: had the largest number of victims, occurred in larger cities, have been precisely located and, due to this baggage of characteristics, have been scientifically described (e.g. the Kielce pogrom of July 1946). It should be assumed that these at least 200 places of crimes against the survivors - this approximate number shows that a clear figure is impossible to arrive at this early stage of research - will never be remembered in any form.

In striving to identify these tragic points in the historical time-space, it should be of primary importance to make them parts of the collective consciousness. It is therefore paramount that the locations of these events become places of focus for dramatic Jewish histories, assume characteristics that would transform them into carriers of memory of the victims. They should become the attachment points for the local, and non-local, identity (a source of realisation that it happened in this particular town, or its vicinity, here, no matter how hard it is now to say where exactly).

Keywords: Jews, Holocaust, anti-Jewish violence, post-war period, places of memory, places of non-remembrance, non-places of remembrance.

Dr hab. Andrzej Rykała, prof. UŁ

Uniwersytet Łódzki

Wydział Nauk Geograficznych

Katedra Geografii Politycznej, Historycznej i Studiów Regionalnych

90-142 Łódź, ul. Kopcińskiego 31

e-mail: andrzej.rykala@geo.uni.lodz.pl 